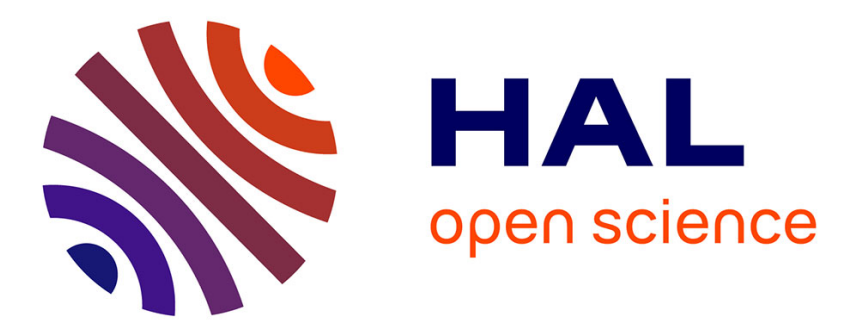

\title{
Environmental assessment of proton exchange membrane fuel cell platinum catalyst recycling
}

Lucien Duclos, Maria Lupsea, Guillaume Mandil, Lenka Svecova, Pierre-Xavier Thivel, Valérie Laforest

\section{- To cite this version:}

Lucien Duclos, Maria Lupsea, Guillaume Mandil, Lenka Svecova, Pierre-Xavier Thivel, et al.. Environmental assessment of proton exchange membrane fuel cell platinum catalyst recycling. Journal of Cleaner Production, 2017, 142 (Part 4), pp.2618-2628. 10.1016/j.jclepro.2016.10.197 . emse01392130

\section{HAL Id: emse-01392130 \\ https://hal-emse.ccsd.cnrs.fr/emse-01392130}

Submitted on 12 Feb 2018

HAL is a multi-disciplinary open access archive for the deposit and dissemination of scientific research documents, whether they are published or not. The documents may come from teaching and research institutions in France or abroad, or from public or private research centers.
L'archive ouverte pluridisciplinaire HAL, est destinée au dépôt et à la diffusion de documents scientifiques de niveau recherche, publiés ou non, émanant des établissements d'enseignement et de recherche français ou étrangers, des laboratoires publics ou privés. 


\title{
Environmental assessment of proton exchange membrane fuel cell platinum catalyst recycling
}

\author{
Lucien Duclos $^{\mathrm{a}}$, Maria Lupsea ${ }^{\mathrm{a}}$, Guillaume Mandil ${ }^{\mathrm{b}}$, Lenka Svecova ${ }^{\mathrm{a}, \mathrm{c}}$, Pierre-Xavier Thivel $^{\mathrm{a}, \mathrm{c}}$, Valérie \\ Laforest $^{\mathrm{d}^{*}}$ \\ ${ }^{a}$ Univ Grenoble-Alpes, CNRS, LEPMI, F-38000 Grenoble, France \\ ${ }^{b}$ Univ Grenoble-Alpes, CNRS, GSCOP, F-38000 Grenoble, France \\ ${ }^{c}$ Réseau sur le Stockage Electrochimique de l'Energie (RS2E), FR CNRS 3459, France

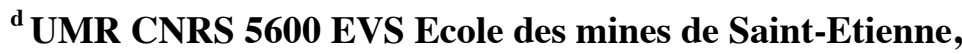 \\ I. Fayol 158 cours Fauriel, Saint-Etienne, F42023 \\ *laforest@emse.fr
}

\begin{abstract}
A proton exchange membrane (PEM) fuel cell, an alternative to combustion processes that consume fossil resources, is used to convert energy stored in the form of hydrogen into electricity. The membrane-electrode assembly (MEA), the core of this system, contains platinum, a noble metal, which is a limited resource. This paper presents an environmental assessment of a recycling process for the platinum catalyst contained in the MEA of a PEM fuel cell. During this study, four hydrometallurgical platinum recovery processes from Pt/C particles have been developed at the laboratory scale. The considered process alternatives are composed of the four following steps: leaching, separation, precipitation and filtration. Approximately $76 \%$ of the platinum can be recovered as $\left[\mathrm{NH}_{4}\right]_{2} \mathrm{PtCl}_{6}$ salt using the most efficient process alternatives. In this case, platinum leaching is carried out with a mixture of $\mathrm{H}_{2} \mathrm{O}_{2}$ and $\mathrm{HCl}$, followed by liquid/liquid platinum extraction and a precipitation step.

The environmental assessment was performed using the SimaPro 8 tool coupled with the EcoInvent 3.1 database. The environmental impacts were estimated for a $25 \mathrm{~cm}^{2}$ active area MEA considering the production and end-of-life stages of the MEA life-cycle using the CML-IA baseline V3.02 method. The results show that more than half of the main impacts of the MEA life-cycle can be avoided for four relevant impact categories if platinum is recovered in the end-of-life of the product.
\end{abstract}

Keywords: PEMFC, LCA, platinum, recycling, hydrometallurgy

\author{
Abbreviations \\ (E) Energy \\ (Em) Emissions
}


(CCB) Catalyst coated backing

(CCM) Catalyst coated membrane

(CML) Institute of Environmental Sciences of the Faculty of Science of Leiden University

(FW-ecotox) Fresh water ecotoxicity

(GDL) Gas diffusion layer

(GWP) Global warming potential

(ICE) Internal combustion engine

(LCA) life-cycle assessment

(M-ecotox) Marine aquatic ecotoxicity

(MEA) Membrane-electrode assembly

(ODP) Ozone layer depletion

(PEM) Proton exchange membrane

(PEMFC) Proton exchange membrane fuel cell

(PET) Polyethylene terephthalate

(Pt) Platinum

(PTFE) Polytetrafluoroethylene

(RM) Raw material

(T-ecotox) Terrestrial ecotoxicity

(TFE) Tetrafluoroethylene

(TOPO) Trioctylphosphine oxide

\section{Introduction}

The current growth in energy demand and increase in resource depletion due to energy consumption have led to the development of new systems for energy production. To meet this demand and reduce the environmental impact resulting from energy production, renewable energy sources based on wind or solar energy have been increasingly used; nevertheless, they cannot guarantee stability in the amount of produced energy, partly because of unstable weather conditions. Electrochemical energy storage, in the form of hydrogen, is a good option to overcome the fluctuations of weather. Proton exchange membrane (PEM) fuel cells could be an alternative energy conversion process, whereby electricity is produced by a reaction between oxygen and hydrogen; the only by-products are heat and water. The redox reactions involved are catalysed by platinum nanoparticles present on the electrodes. The core of a PEM fuel cell is a membraneelectrode assembly in which reactions take place and that contains two catalyst layers, both containing platinum. The current study focuses only on the life-cycle of an MEA.

Currently, the global demand for platinum is constant (approximately $200 \mathrm{t}$ per year (Johnson Matthey, 2013)), but very high compared to the available platinum reserves, which are estimated at approximately 10 kt (the total world resources are estimated to be approximately 40 kt (Labbé and Dupuy, 2014)). Moreover, 
only $17 \%$ of the used platinum is recycled (see Table 1). In addition, in the scenario of large-scale production of PEM fuel cells, platinum extraction costs would represent between 30 and $40 \%$ of the fuel cell manufacturing costs; these values were calculated using data from the literature (James and Spisak, 2012). Taking into account the price of this metal and its limited supply, it is necessary to develop an efficient recycling process regarding the end-of-life stage of MEAs from fuel cells. At the same time, the environmental impacts of such platinum recycling processes have to be compared to the burden of primary platinum production.

Table 1: World platinum market in 2012 (Johnson Matthey, 2013).

Until now, several studies have been performed on assessing the environmental impact of the PEM fuel cell life-cycle. A LCA, taking into account the production and use stages, was carried out by Garraín (2011) to compare PEM fuel cell cars to internal combustion engine vehicles. Two comparative environmental studies between PEM fuel cell and ICE cars (Sørensen and Roskilde, 2004; Hussain et al., 2007), have been performed for three life-cycle stages (production, use and end-of-life stages), but without taking into account platinum recycling. Pehnt $(2001,2003)$ performed a LCA of a fuel cell system for mobile and stationary applications, considering the production, use and end-of-life stages. In these studies, an average catalyst recycling rate was defined by the author. More recently, Simons and Bauer (2015) studied the LCA of a PEM fuel cell system for road passenger vehicle applications. Their study concerned all life-cycle stages of the fuel cell and was based on data provided by the U.S. Department of Energy. However, data concerning the recycling of used MEAs in the end-of-life of the fuel cell are based on the adaptation of similar hydrometallurgical recycling processes. Thus, none of the already published LCA studies dealing with PEM fuel cells includes real data for the recovery of platinum and other MEA components.

In this context, the objectives of the current study are: (i) to assess the environmental impact of the whole life-cycle of a MEA and (ii) to help decision making for choosing a Pt recycling process from these MEAs based on an assessment of the environmental impact via the life-cycle assessment methodology. Thus, a production scenario that only uses primary platinum (i.e., directly from the extraction plant, including transport for consumption in Europe) is compared to four recycling scenarios, including platinum recovered from MEAs via a hydrometallurgical process (Duclos et al., 2016).

\section{PEM fuel cells}

A MEA is a stack cell comprising two GDLs, two electrodes (an anode and a cathode) and an ion conducting membrane that is occasionally supported by a polymeric gasket (see Figure 1). When the fuel cell operates, hydrogen is oxidised at the platinum surface of the anode into $\mathrm{H}^{+}$and electrons. Electrons and $\mathrm{H}^{+}$ions migrate to the cathode, respectively, through an electric circuit and through the membrane. At the cathode surface, oxygen is reduced and reacts with $\mathrm{H}^{+}$ions to produce water. The reaction is exothermic, and some heat is co-produced. Electrons moving between the electrodes create an electric current. 
MEAs are placed between two bipolar plates and have multiple roles: (i) to supply fuel and oxidant to the reactive sites, (ii) to remove reaction products, (iii) to collect the produced current, (iv) to provide mechanical support for the cells in the stack and (v) to evacuate reaction heat. A stack of several MEAs and bipolar plates placed successively between current collectors and packed with two end-plates, nuts and bolts is called the PEM fuel cell. Additionally, gaskets are used to provide the system with gas-tightness and to adjust the compression of the bipolar plates. The number of MEAs in a stack can vary relative to the desired power. The current study was carried out at the MEA scale and not at the whole fuel cell scale.

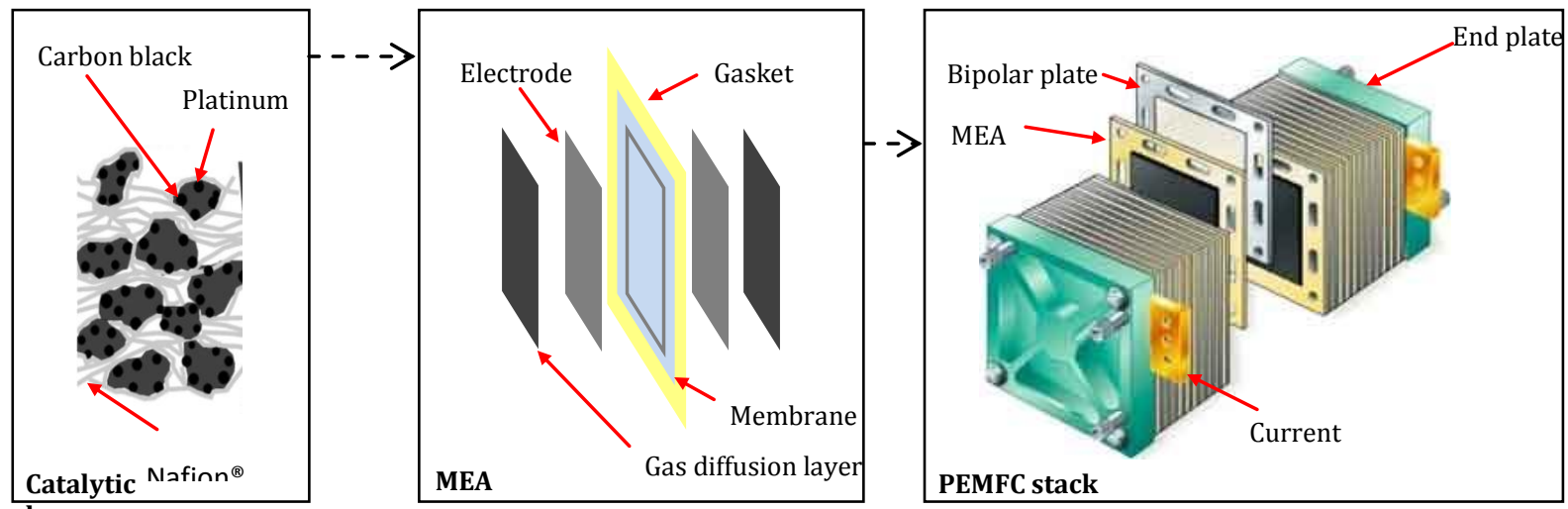

Figure 1: Fuel cell, MEA and electrode components (adapted from: http://www.theengineer.co.uk).

\subsection{MEA production process}

As mentioned in the section above, the MEA is composed of one membrane, two electrodes and two GDLs. The sulfonated fluoropolymer membrane (usually Nafion ${ }^{\circledR}$ ) and GDL are manufactured separately. The assembly is achieved by applying a so-called "electrode-ink" on one of the components, i.e., either on the membrane named CCM, or on the GDL named CCB. The electrode-ink is obtained by mixing platinised carbon $(\mathrm{Pt} / \mathrm{C})$ with a solution containing $\mathrm{Nafion}^{\circledR}$, water, propanol and other aliphatic alcohols. The actual printing of the ink on the components can be realised at a large scale by two processes: (a) screen-printing (Wang et al., 2015) or (b) inkjet printing (Towne et al., 2007). An additional step can be introduced for CCM manufacturing by forming the catalyst layer on a Teflon support before transferring it onto the membrane by hot pressing (Jung et al., 2012). If the screen-printing process is used, viscous alcohols are added to the ink to obtain a paste. A gasket can be optionally added to the assembly to increase its resistance. Finally, all of the layers are hot-pressed so that solvents evaporate and the layers stick together.

The platinised carbon can be manufactured either by reducing a platinum salt on a carbon powder support by various methods, such as an impregnation reduction method in the liquid or gaseous phase (Veizaga and al., 2012), precipitation reduction method (Liu et al., 2006), or polyols method (Oh et al., 2007) or by sputtering metallic platinum on the carbon support (Fedotov et al., 2013). It has been previously demonstrated that platinum use during this stage has a significant influence on the stack production environmental impact (Pehnt, 2003; Pehnt et al., 2003). 
Nafion ${ }^{\circledR}, \mathrm{CF}_{2}=\mathrm{CFO}-\mathrm{C}_{3} \mathrm{~F}_{6}-\mathrm{O}-\mathrm{C}_{2} \mathrm{~F}_{4}-\mathrm{SO}_{2} \mathrm{~F}$, is produced by copolymerisation of tetrafluoroethylene and a perfluoroalkyl sulfonyl fluoride (Jones, 2012). Then, the membrane is manufactured using an extrusion process at the industrial scale. Finally, the sulfonic groups are hydrolysed by a reaction with a hot solution of $\mathrm{NaOH}$ or $\mathrm{KOH}$ and the ionomer is converted to the $\mathrm{H}^{+}$form with a strong acid, such as $\mathrm{HNO}_{3}$.

GDLs are made of carbon paper (Park et al., 2008) or carbon cloths (Velayutham, 2011) that are waterproofed using PTFE (between 10 and 20 weight $\%$ ). The carbon paper is manufactured by hot pressing and carbonizing carbon fibres aggregated with approximately 15\% phenolic resin (Hung et al., 2015), whereas carbon cloth is made of knitted carbon fibres. The carbonaceous support is coated with a microporous layer composed of carbon black treated with PTFE to improve PEM fuel cell performance.

\subsection{Platinum recycling processes}

A multi-step process had to be carried-out to recycle the platinum from the used fuel cells. The simplest procedures with a negligible environmental impact are mechanical steps, such as the disassembly of a stack into its separate components, i.e., the MEAs, gaskets, bipolar plates, current collectors, and all of the mechanical components (nuts, bolts, etc.). Nevertheless, more complex processes have to be considered to delaminate the different layers constituting the MEA to recover the membrane separately from the catalyst coating, i.e., platinum. Depending on the manufacturing process (see details in $\S 2.2$ ), the GDL could also be separated mechanically from the CCM. However, mechanical dismantling of the fuel cell was not considered in this study, whereas recycling was only realised at the MEA level with a focus on Pt recovery.

Several processes have been developed for platinum recovery from different substrates, such as: (i) pyrometallurgy (metal melting) (Benson et al., 2000), (ii) hydrometallurgy (metal dissolution) (Barakat and Mahmoud, 2004) or (iii) substrate removal by dissolution (Xu et al., 2010) or incineration (Zhao et al., 2014). In the current study, four hydrometallurgical process alternatives are compared to recover platinum. The method developed in this research is efficient and allows high metal purification. Moreover, platinum can be recovered as a solid $\left[\mathrm{NH}_{4}\right]_{2} \mathrm{PtCl}_{6}$ salt and reused to manufacture new catalyst materials (Verde et al., 2014). The considered process alternatives were developed at the laboratory scale by the authors and are detailed in (Duclos et al., 2016). Each process is thus composed of the following steps: (i) leaching, (ii) extraction (via extraction or resin), (iii) regeneration (of the extractant or the resin), (iv) precipitation, and (v) filtration of the final product i.e., $\left[\mathrm{NH}_{4}\right]_{2} \mathrm{PtCl}_{6}$ (Figure 2). Two different leachates (acidified solutions of $\mathrm{H}_{2} \mathrm{O}_{2}$, respectively $\mathrm{HNO}_{3}$ ) were used for each recycling process alternative. Moreover, two separation (extraction and regeneration) paths were considered: (1) using ion exchange resin adoption (tested resin: Lewatit-MP-62) and (2) using solvent extraction (tested extractant/diluent couple: Cyanex ${ }^{\circledR}$ 923/octanol). The four recycling process alternatives were tested and optimised. To run the experiments, $25 \mathrm{~cm}^{2} \mathrm{CCM}$ samples with platinum loading of $1 \mathrm{mg}^{\cdot} \mathrm{cm}^{-2}$ (provided by Paxitech society, Echirolles, France) were used. These samples were cut into small pieces $\left(4 \mathrm{~mm}^{2}\right)$. The experimental results presented in section $\$ 3.3$ correspond to tests performed on CCMs. 


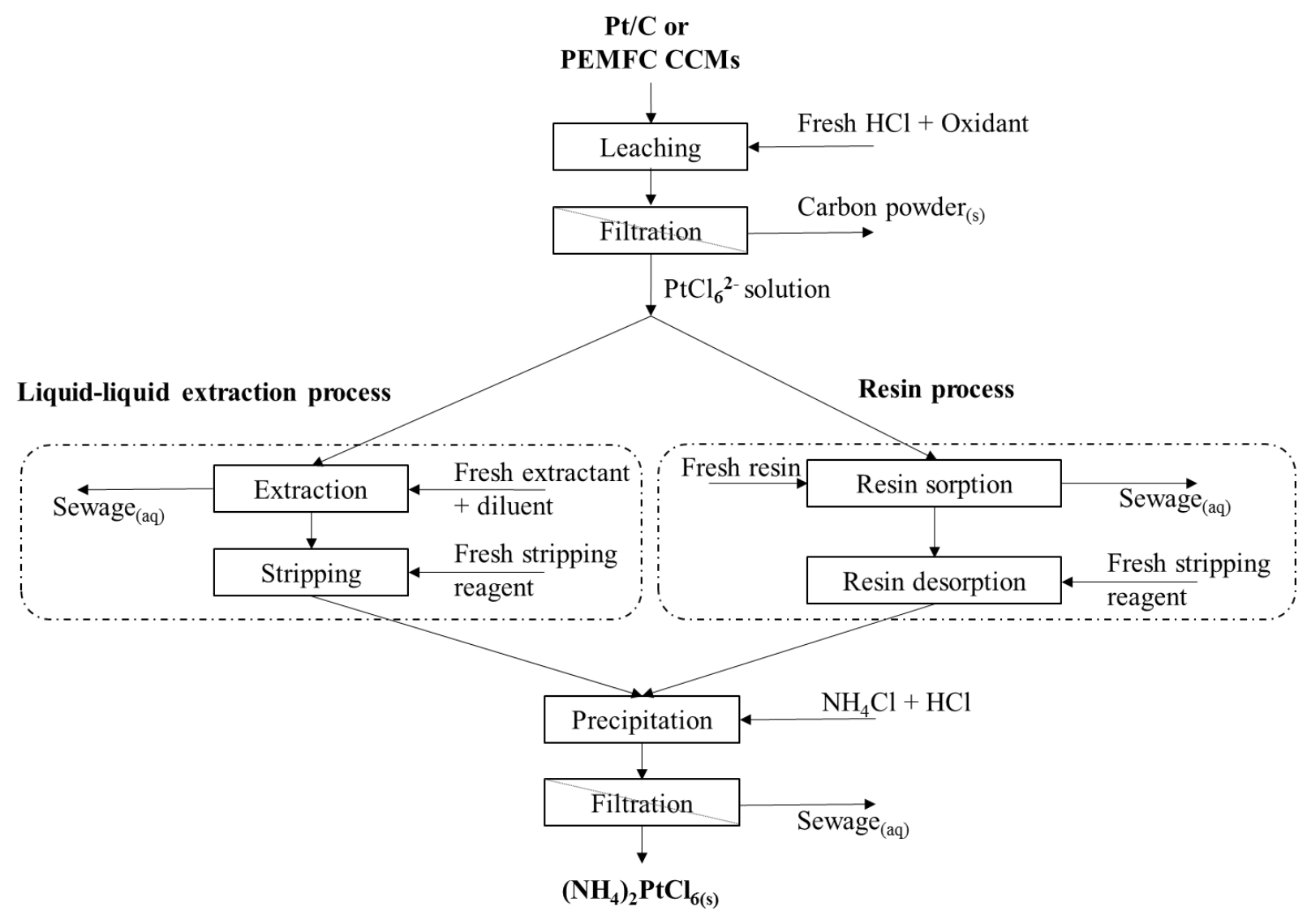

Figure 2: Flow-charts of the two studied platinum recovery processes: (left) the resin recovery process and (right) the liquid/liquid extraction recovery process (Duclos et al., 2016).

\section{Environmental impact assessment methodology}

LCA is a tool that is used to "assess environmental impacts and potential environmental impacts throughout a product's life-cycle" from cradle to grave (i.e., from raw material extraction, to disposal and recycling of the final product after use). The ISO 14040 and 14044 standards provide general guidance to perform a LCA, which is composed of four main phases: (1) goal and scope definition, (2) inventory analysis, (3) life-cycle impact assessment and (4) interpretation.

Modelling and simulation of the impacts was performed using the SimaPro 8 tool coupled with the EcoInvent 3.1 database. The environmental impacts were assessed using the CML-IA baseline V3.02 method. This method was used previously by Zucaro et al. (2013) in a LCA of a molten carbonate fuel cell, which is in accordance with the guideline for performing LCAs on fuel cells (Masoni and Zamagni, 2011).

\subsection{Step 1: goal and scope definition}

The first objective of the current LCA study is to note the main environmental burdens associated with MEA production. The second goal is to identify which of the four platinum recovery process alternatives has the lowest environmental impact and to integrate the chosen alternative in the LCA of a MEA. Thus scenario 
(1), using primary platinum, is compared to a scenario (2), using primary and recycled platinum (see Figure 3).

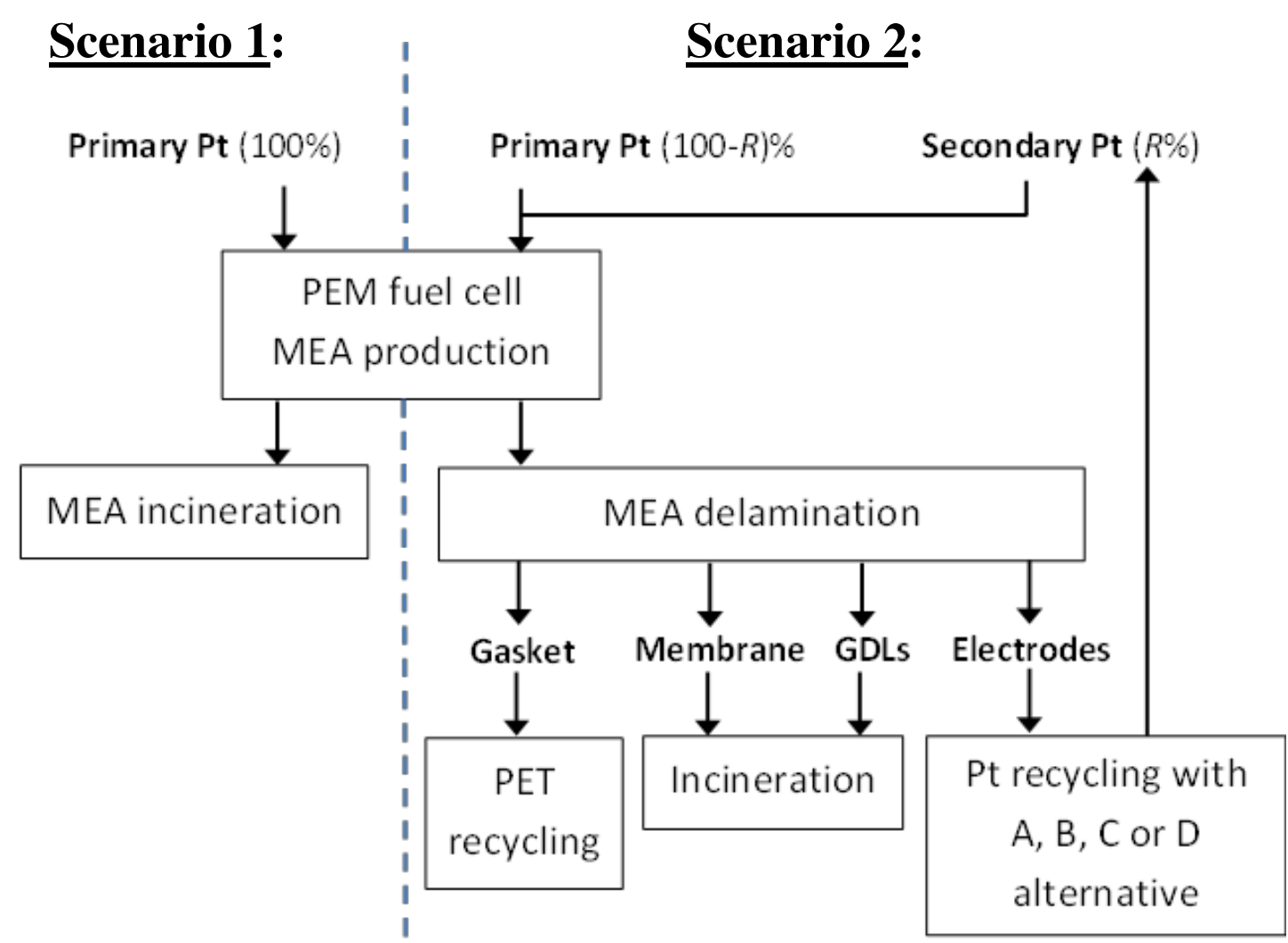

Figure 3: Global model diagram of incineration and recycling scenarios, where $R$ is the recovery efficiency of a process alternative.

The impact is assessed at the MEA scale for technical reasons explained in section §2.3. Thus, the functional unit was defined as: manufacturing and recycling one MEA that disposes of $25 \mathbf{c m}^{\mathbf{2}}$ of active area (50 $\mathrm{cm}$ of electrode layer). Nevertheless, according to the recommendations made by the FC-Hy Guide (Masoni and Zamagni, 2011), the results can further be easily correlated to the electrical power at a stack scale based on the power density (approximately $0.7 \mathrm{~W} \cdot \mathrm{cm}^{-2}$ ).

The main stages of the MEA life-cycle are: (i) production stage (i.e., assembly of the membrane, electrodes and gas diffusion layers), (ii) transport to the use facility, (iii) use stage (within a vehicle, in the case of a transport application, for example) and (iv) end-of-life (incineration or platinum recycling). However, only the production and the end-of-life stages are considered here. Neither use stage, which refers to the use of $\mathrm{H}_{2}$ as fuel, nor the transport stage are taken into account.

Actually, depending on the production process of $\mathrm{H}_{2}$, e.g., from biomass (gasification or biological production by microorganisms), by solar energy, by wind energy or from fossil fuels, the impacts could be more or less important. Moreover, several studies have already been performed to evaluate the environmental impacts of various production processes of $\mathrm{H}_{2}$ (Bhandari et al., 2013; Iribarren et al., 2014). It was previously demonstrated (Pehnt, 2001) that the manufacturing stage has a significant influence on the 
generated environmental impacts over the whole life-cycle of a PEM fuel cell compared to hydrogen production (i.e., use stage). This fact has further been confirmed by two more accurate studies (Pehnt, 2003; Simons and Bauer, 2015), which compared various processes for hydrogen production. However, the lifecycle of $\mathrm{H}_{2}$ production, i.e., the use stage of PEM fuel cell, does not include any platinum consumption. Once a $\mathrm{H}_{2}$ production process is fixed, this phase could be considered to be a constant black-box in the lifecycle of a MEA (and PEM fuel cell as the final objective).

Concerning the transport phase, data for the inventory depend on the chosen scenario, i.e., production and use in Europe, or other continents, and so on. Data for this phase are very scarce and not of interest for the studied case. Indeed, the main interest of this study is to compare the environmental impact of the use of primary platinum for PEM fuel cell production, with the use of secondary platinum from a hydrometallurgical recycling process. In the future, integration in the LCA at the PEM fuel cell scale could be envisioned easily.

\subsection{Step 2: inventory analysis}

Data concerning the inventory were mainly taken from the EcoInvent 3.1 database. Nevertheless, several processes and materials had to be defined to build a reliable model (see Table 2). The new processes and materials built are described in detail below.

Production stage. Four main compounds are included in the model to simulate the production stage of a MEA: (i) the membrane, made of a sulfonated fluoropolymer; (ii) the GDL, made of PTFE waterproofed carbon black and carbon paper; (iii) the gasket for the membrane, made of polymer whose composition is close to PET; and (iv) the catalyst layers, made of Nafion ${ }^{\circledR}$ and carbon supported platinum (Pt/C). The considered composition per FU is given in Table 2, along with references.

\section{Table 2: MEA manufacturing data.}

Data on energy consumption and raw material consumption for the production stage were obtained from the LITEN department of the CEA, which manufactures MEAs for research applications using the screen printing method. However, for reasons of confidentially, some information cannot be provided by the manufacturer. The missing data were replaced with data found in the literature (see details in Table 2). Regarding GDL and membrane pre-treatment, material losses of, respectively, 15 and 20\% were considered during the MEA manufacturing stage. Concerning catalyst synthesis, liquid phase impregnation reduction and sputtering methods were chosen to model $\mathrm{Pt} / \mathrm{C}$ production, respectively, from platinum salt or pure platinum metal.

As shown in Table 2, some objects cannot be found in the EcoInvent database; therefore, new materials were defined to simulate, as precisely as possible, the MEA composition (Table 3); whereas some examples are presented below: 
- $\quad$ Nafion ${ }^{\circledR}$, which is a sulfonated tetrafluoroethylene based fluoropolymer-copolymer, found in the membrane and the catalyst layers,

- carbon supported platinum $(\mathrm{Pt} / \mathrm{C})$ found in the catalyst layers.

Material amounts were calculated according to the composition of new materials. In this case, energy consumption and material losses were considered negligible and $100 \%$ synthesis yields were considered. For example, PTFE and sulfuric acid contents, respectively, $\%_{P T F E}$ and $\%_{\mathrm{H}_{2} \mathrm{SO}_{4}}$, were calculated with Eq.1 and Eq. 2. In Eq.1, Nafion ${ }^{\circledR}$ is considered to be a product containing $\mathrm{SO}_{3}$ groups and PTFE. Eq.2 demonstrates the calculation of the amount of sulfuric acid needed to produce the Nafion ${ }^{\circledR}$ sulfonic groups.

$\%_{\text {PTFE }}=1-\frac{M_{\mathrm{SO}_{3}}}{M_{\text {Nafion }}}$

$\%_{\mathrm{H}_{2} \mathrm{SO}_{4}}=\frac{M_{\mathrm{SO}_{3}}}{M_{\mathrm{Nafion}}} \times \frac{M_{\mathrm{H}_{2} \mathrm{SO}_{4}}}{M_{\mathrm{SO}_{3}}}=0.15 \times \frac{M_{\mathrm{H}_{2} \mathrm{SO}_{4}}}{M_{\mathrm{SO}_{3}}}$

where $M_{x}$ represents the molar mass of chemical x.

\section{Table 3: Additional products in SimaPro.}

The EcoInvent database includes several "default" processes, some of them being very precise and specific. All processes are characterised from cradle to grave, including energy and raw material consumption and emissions. Nevertheless, a couple of new processes have been redefined and modelled with SimaPro for the current study:

- evaporation processes of various solvents used during the production stage (e.g., glycerol, propanol and water evaporation), considering chemical emissions to the air

- energy consumption of the MEA assembly process.

End-of-life stage: incineration scenario (1). The end-of-life of the gasket and catalyst layers was modelled with SimaPro using the "Hazardous waste, for incineration" process from EcoInvent database, designed for special waste with an unknown composition. The impact of hydrogen fluoride emissions due to the incineration of products containing high fluorine amounts was modelled by creating new waste treatment processes using the EcoInvent "Waste polyvinylfluoride" incineration process. The burden of the polyvinylfluoride (PVF) incineration process was calculated using Eq. 3 as $\% \mathrm{~F}_{\text {product }}$ and $\% \mathrm{~F}_{\mathrm{PVF}}$, which are the fluoride contents of a product and of PVF, respectively. The incineration processes modelled for Nafion ${ }^{\circledR}$ and PTFE to assess the membrane and GDL end-of-life impact are shown in Table 4. The GDL i.e., the microporous layer, and carbon paper contain 15\% PTFE and 85\% of other organic compounds, so its end-oflife was modelled by creating a new waste scenario taking into account $15 \%$ of the PTFE treatment process and $85 \%$ of the "Hazardous waste, for incineration" treatment process.

$P V F$ incineration $=\frac{\% F_{\text {product }}}{\% F_{P V F}}=\frac{\% F_{\text {product }}}{0.53}$

Table 4: Additional waste treatment processes in SimaPro. 
End-of-life stage: recycling scenario (2). In the case of GDL or membrane recycling, the first step in the recycling process is MEA delamination. Nafion ${ }^{\circledR}$ (contained in membrane and electrodes) can be dissolved in an autoclave with a water/alcohol mixture under high pressure and temperature (Stephen and Walther, 2005). The membrane can also be separated from MEAs with a water/alcohol mixture at $100{ }^{\circ} \mathrm{C}$ (Shore, 2006) or at ambient temperature in an ultrasonication process (Oki et al., 2009). For new MEAs, GDL removal can be performed manually and can also be performed in water by stirring (Oki et al., 2009). As there is no reliable information on the material and energy consumption for this step, it has not been included in the inventory.

The end-of-life processes of the four components of the MEA were modelled by incineration or recycling, depending on the available data, as follows: (i) the membrane and the GDL are treated by the waste incinerators defined in Table 4 for the previous scenario, (ii) the gasket made of PET is recycled and (iii) the catalyst layers are recycled to recover Pt using the four process alternatives developed within this research project (namely, A, B, C and D).

Data included in the LCA inventory, i.e., electricity consumption (measured with consumption meters), raw material consumption and emissions (to water, air, and waste), are taken from laboratory tests performed in batch mode on Pt recovery from CCMs. The efficiencies of the four recycling processes are given in Table 5, and the complete process inventory used for process modelling on SimaPro is given in Table 6. Every product mass or energy amount is given for $1 \mathrm{~kg}$ of used platinum treated with the recycling processes. Thus, the values for one used MEA can be calculated in the same units by multiplying the given amounts by $2.5 \cdot 10^{-5}$. For each reagent available in aqueous solution, the mass given in Table 6 was calculated considering the product as a pure chemical without taking into account the amount of water, according to the EcoInvent 3.1 database principle. The experimental results (Duclos et al., 2016) show that the highest platinum recovery efficiency can be obtained after treatment with process $\mathrm{B}\left(\mathrm{H}_{2} \mathrm{O}_{2} /\right.$ Solvent process); thus, this process alternative will be used as an example in the following parts of the paper. Each recycling process was modelled with SimaPro as a black box, taking into account the energy, material inputs and outputs and waste treatment processes. A detailed input/output mass and energy balance of the $\mathrm{H}_{2} \mathrm{O}_{2} / \mathrm{HCl}$ leaching and liquid/liquid extraction process (B) is presented in Figure 4. Platinum is recovered as platinum hexachloroplatinate $\left(\left[\mathrm{NH}_{4}\right]_{2} \mathrm{PtCl}_{6}\right)$ as the main product.

Table 5: Efficiency of the Pt recovery processes (Duclos et al., 2016).

Table 6: Recycling processes energy and mass balance including wastes treatment (amounts per kg of Pt at process inlet). 


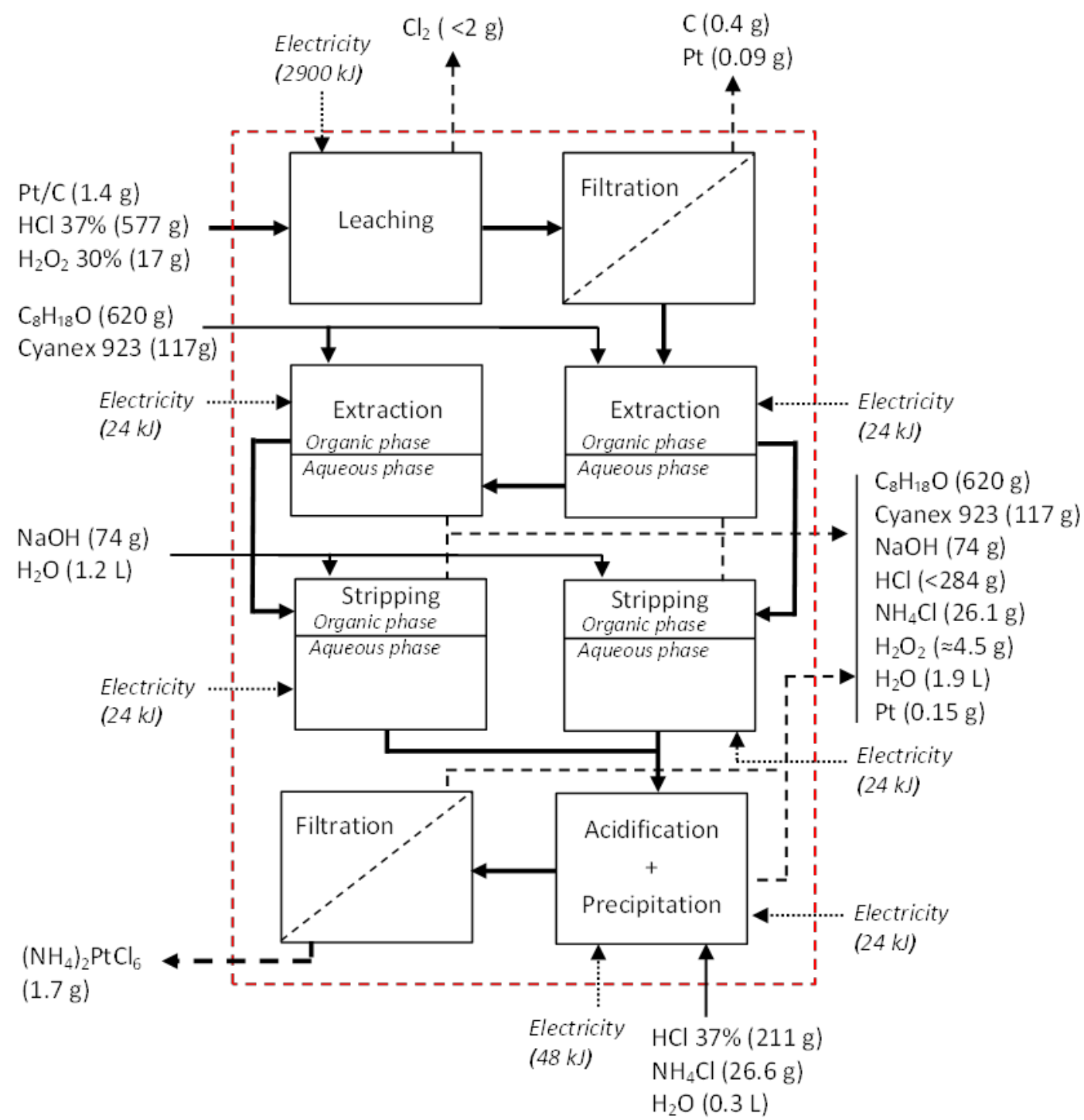

Figure 4: Mass and energy balance of the platinum recovery process from the $\mathrm{Pt} / \mathrm{C}$ of the $\mathrm{H}_{2} \mathrm{O}_{2} / \mathrm{Solvent}_{\text {process }}(\mathrm{B})$.

The Cyane ${ }^{\circledR} 923$ extractant is a mixture of trialkylphosphine oxides that can be considered to be trioctylphosphine oxide. One possible pathway for TOPO synthesis is the reaction between $\mathrm{C}_{8} \mathrm{H}_{17} \mathrm{MgBr}$ (considered as $\mathrm{C}_{8} \mathrm{H}_{18}$ on SimaPro) and $\mathrm{POCl}_{3}$ (Kadous et al., 2009). Thus, Cyanex ${ }^{\circledR} 923$ production was modelled on SimaPro with the methodology adopted for Nafion ${ }^{\circledR}$ (see composition in Table 3).

The waste-resins used in the recycling processes (C and D) are entered in the "Spent anion exchange resin from potable water production" disposal process, which is available in the EcoInvent database; the organic solvents are treated in the "Spent solvent mixture" specific treatment process available in the EcoInvent database for organic products. Nafion ${ }^{\circledR}$ and carbon are incinerated in the "Hazardous waste, for incineration" incinerator. The aqueous effluent treatments are modelled using the "Wastewater, average $\{\mathrm{CH}\}$ treatment of capacity 4.7E10 1/year". Missing processes, such as acid neutralisation units, were created with SimaPro. The 
$\mathrm{Cl}_{2}$ produced during the leaching stage was treated by bubbling through a $\mathrm{NaOH}$ solution ${ }^{1}$. The emitted amount was overestimated to calculate the maximal sodium hydroxide solution volume needed to treat the gaseous emissions. This treatment process was not included in the inventory because of its low environmental impact in comparison with the other hydrometallurgical process steps for the four hydrometallurgical alternatives.

After the recovery of $\left[\mathrm{NH}_{4}\right]_{2} \mathrm{PtCl}_{6}$ powder, new platinised carbon was produced, and new electrodes were manufactured using this recycled Pt salt. The liquid impregnation method, followed by a liquid phase reduction (Veizaga and al., 2012), was chosen to model Pt/C catalysts remanufacture in scenario (2). Indeed this method is very efficient (higher than 99\%) and has a low environmental impact in comparison with the other techniques.

The incineration scenario and the recycling scenario, including process B modelled with SimaPro, are described in Figure 5. Products are represented by square boxes and processes by rounded boxes. EcoInvent products and processes are coloured, whereas the newly created ones are white. Full lines represent elementary flows, i.e., raw material, energy and emissions flows and while dotted lines represent logical connections between various products and processes. The main platinum flow, including recycling processes, is represented with a bold dotted line.

\footnotetext{
${ }^{1}$ http://www.worldchlorine.org/wp-content/themes/brickthemewp/pdfs/chlorine_safety.pdf
} 


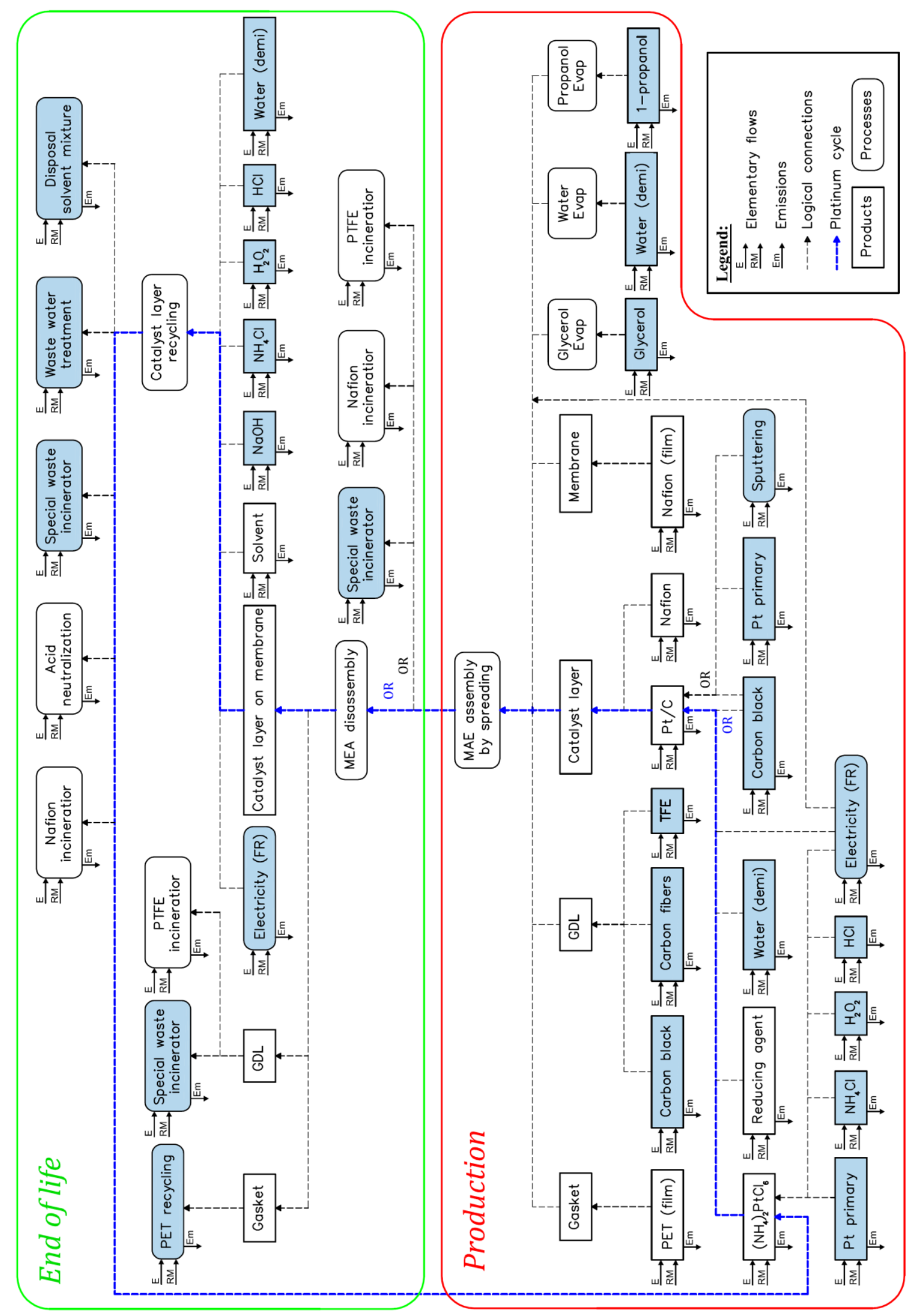

Figure 5: SimaPro model diagram of PEMFC MEA production and end-of-life stages.

3.3. Step 3: life-cycle impact assessment 
The impacts are assessed using the CML-IA baseline V3.02 method and the associated impact indicators. Thus, the environmental impact indicators (along with characteristic units) shown in Table 7 are evaluated.

Table 7: CML-IA baseline V3.02 method impact categories.

\section{Impact assessment}

Within the two considered scenarios, as described in section $\$ 3.2$, incineration of all components was chosen as the end-of-life option in scenario (1), while recycling was performed in scenario (2). In scenario (1), primary platinum is used for the production stage (i.e., directly from the extraction site) and an open loop scenario is envisaged. For scenario (2), the cycle between production and end-of-life is closed by $\mathrm{Pt}$ recycling. Thus, platinum for the production stage is a mixture between recycled (in the end-of-life stage from a used MEA) and primary platinum. The ratio of primary platinum is calculated as a function of the recovery efficiency of platinum in the end-of-life stage. Concerning the end-of-life of a MEA cell, platinum is recovered by four hydrometallurgical process alternatives, as previously described, while other components are incinerated (e.g., membrane, GDL) or recycled (PET support).

\subsection{Identification of the most impacting stage for the incineration scenario}

The impact was assessed for each process and product of scenario (1), using the CML-IA baseline V3.02 method - the most impacting stage burdens are shown in Figure 6. The results show that platinum production (primary platinum as a raw material) represents the major component of the impacts over the MEA life-cycle for almost all of the impact categories, except the global warming potential and ozone layer depletion. The second main factor is the production of tetrafluoroethylene (mainly used in the membrane manufacturing step), which contributes to each impact and represents, respectively, $40 \%$ and more than $99 \%$ of the total burdens for the GMP and the ODP categories. Indeed, fluorocarbon gases are emitted during TFE manufacturing; these pollutants have a large global warming potential and lead to ozone layer depletion.

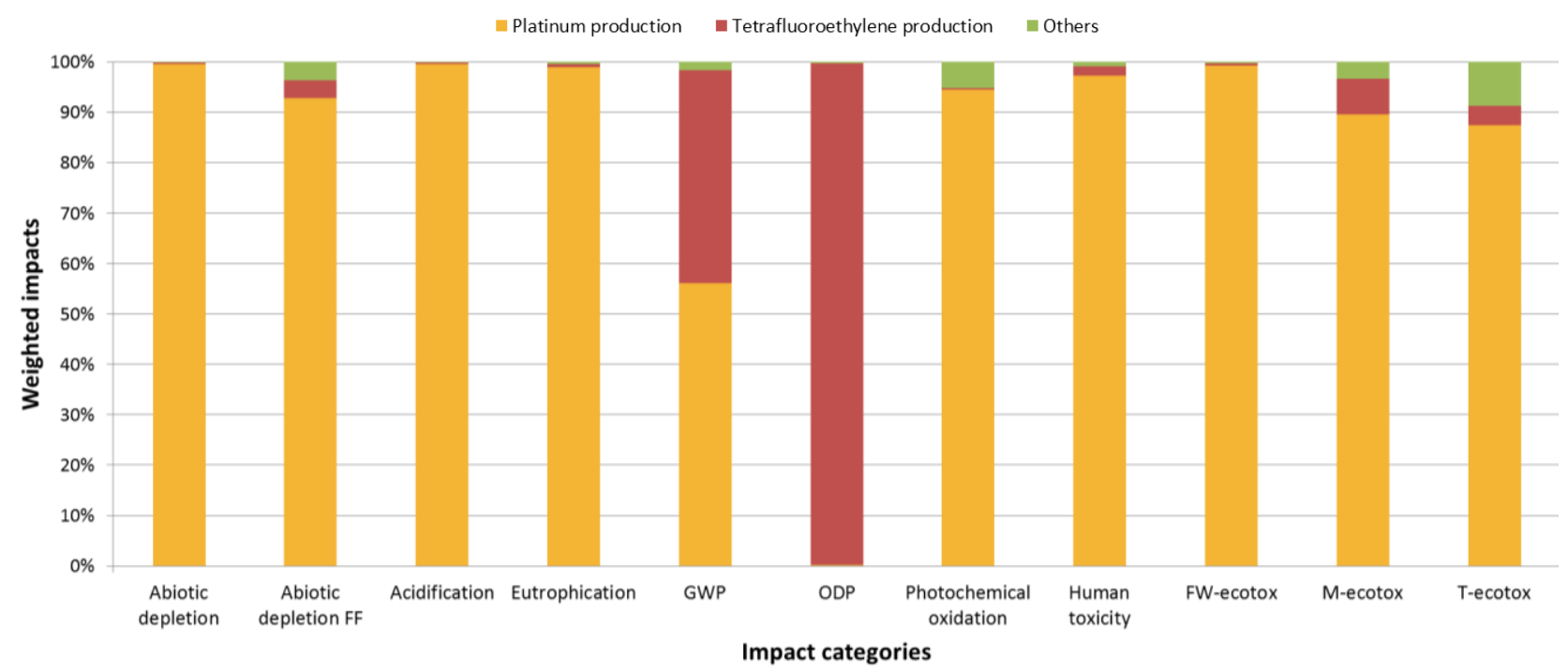


Figure 6: MEA life-cycle hot-spot identification from the scenario (1).

Platinum extraction and purification have a large environmental impact mainly because of trace metal (beryllium, mercury, nickel, selenium, etc.) emissions to water and nitrogen oxide, hydrogen fluoride and sulphur dioxide emission to air during pyrometallurgical and hydrometallurgical purification steps (EcoInvent inventory). The results were calculated for CCMs manufactured by Paxitech with a platinum loading of $1 \mathrm{mg} \cdot \mathrm{cm}^{-2}$. Currently, lower platinum loadings are being used in fuel cells (between 0.1 and 1 $\mathrm{mg} \cdot \mathrm{cm}^{-2}$ ). The simulations performed with such loadings show that platinum use would still represent a large portion of PEM fuel cell life-cycle impacts. Consequently, platinum recovery could be the solution for both reducing the environmental impacts of the life-cycle of MEA (production \& end-of-life) and PEM fuel cell cost in the long term in the case of large scale production. Thus, catalyst recovery has to be taken into account before other components' recycling.

\subsection{Comparison of the four platinum recycling processes: scenario (2)}

The four life-cycle scenarios considering platinum recycling were compared. The results for all of the impact categories were weighted according to the CML-IA baseline V3.02 method to convert the impact units into points; the weighting of each category in the final score is presented in Table 8 for the B process alternative. Three main impact categories can be highlighted from Table 8, i.e., acidification, fresh water aquatic ecotoxicity and marine aquatic ecotoxicity. Concerning the three other processes' recycling scenarios, score weighting shows that these are also the most impacted processes. In addition, abiotic depletion was also selected to take into account metal depletions due to platinum use. Finally, the global warming potential and ozone layer depletion categories were chosen to consider the fluorocarbon gas emissions caused by Nafion ${ }^{\circledR}$ manufacture. The results for the aforementioned impact categories are compared in Figure 7 for the four platinum recovery processes. The least impacting recovery process is the B process, while the most impacting is the A process. Indeed, for the three most impacted categories, i.e., acidification, FW-ecotox and M-ecotox, the impact scores of the MEA life-cycle are the lowest in the case of platinum recycling with the $\mathrm{B}$ process and the highest with the A process. The $\mathrm{B}$ process is more impacting than the $\mathrm{C}$ and $\mathrm{D}$ processes for GWP. Furthermore, the $\mathrm{C}$ and D processes have the same potential environmental burdens for all of the impact categories investigated. 
Table 8: Impact categories burdens in the life-cycle normalised impact score for the scenario (2)-B process.

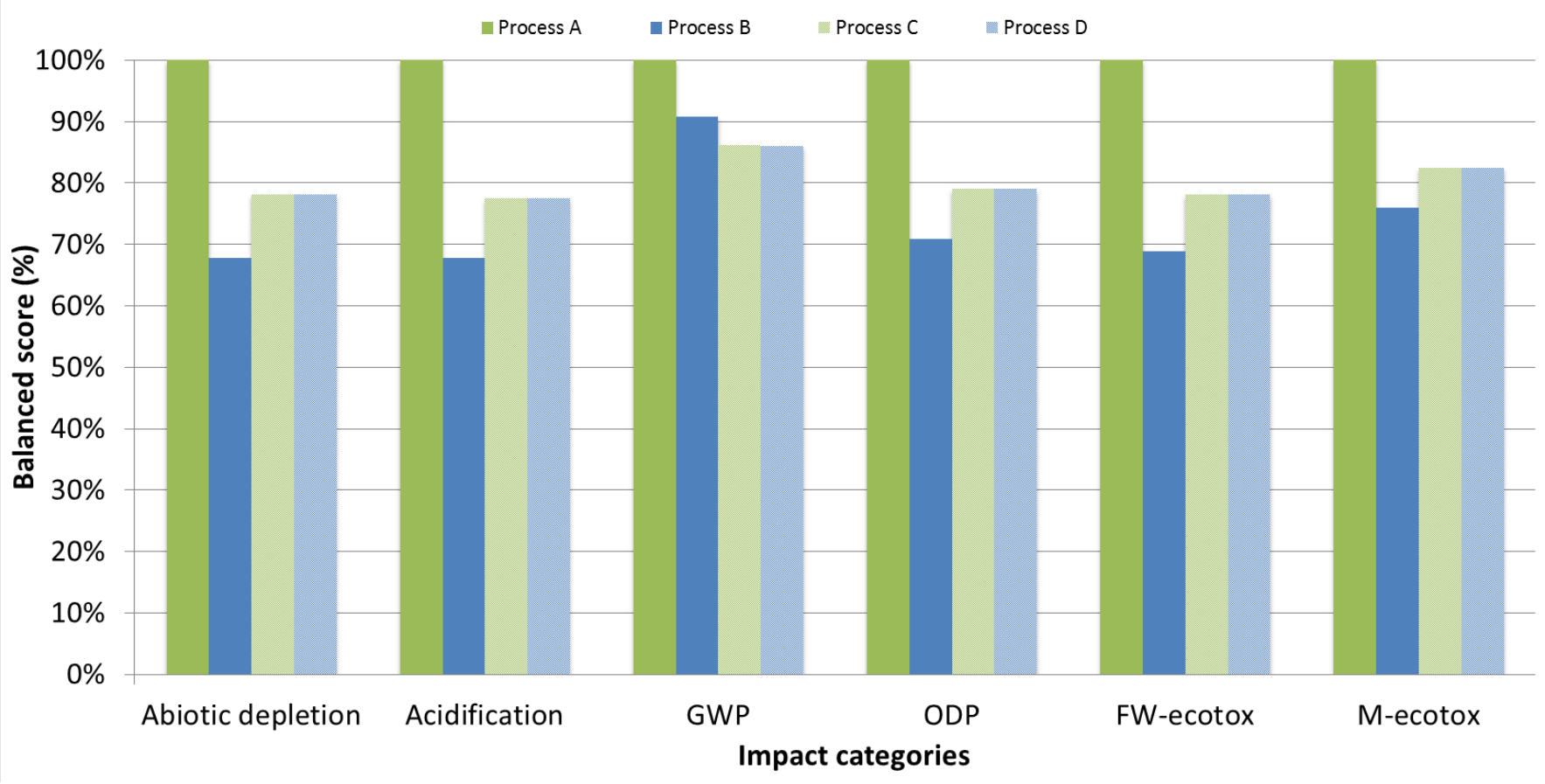

Figure 7: Impact assessment of a $25 \mathrm{~cm}^{2}$ PEM fuel cell MEA considering production and end-of-life stages with scenario (2).

Integrated in the whole life-cycle of the MEA, the impact ratio mostly depends on the recovery efficiency of platinum (Table 5); the more platinum is recovered from the used MEA, the more is used in the production stage. Thus, less primary platinum is consumed. As shown in scenario (1) (see Figure 6), primary platinum is the most impacting of all of the components used in the manufacture of the MEA.

\subsection{Comparison of the recycling and incineration scenarios}

The best process, in terms of potential impact, for the recovery of platinum from used MEAs, i.e., he B process $\left(\mathrm{H}_{2} \mathrm{O}_{2} /\right.$ Solvent), was integrated into the whole life-cycle of the MEA and compared to the scenario of incineration (1). The environmental impact was assessed for each production process and product; the results are shown in Figure 8. Platinum catalyst recycling with the $\mathrm{H}_{2} \mathrm{O}_{2}$ /Solvent process results in a decrease of more than $60 \%$ in the main impact category burdens (Table 8: acidification, abiotic depletion, FW-ecotox and M-ecotox) and more than $30 \%$ of the GWP category over the whole life-cycle. The ODP category is not impacted by platinum recycling because this category is mostly affected by Nafion ${ }^{\circledR}$ production. The results show that primary platinum production remains the most impacting stage, even when MEA recycling is considered. In addition, Nafion ${ }^{\circledR}$ production also has a significant influence on the environmental impact of the MEA's life-cycle. 


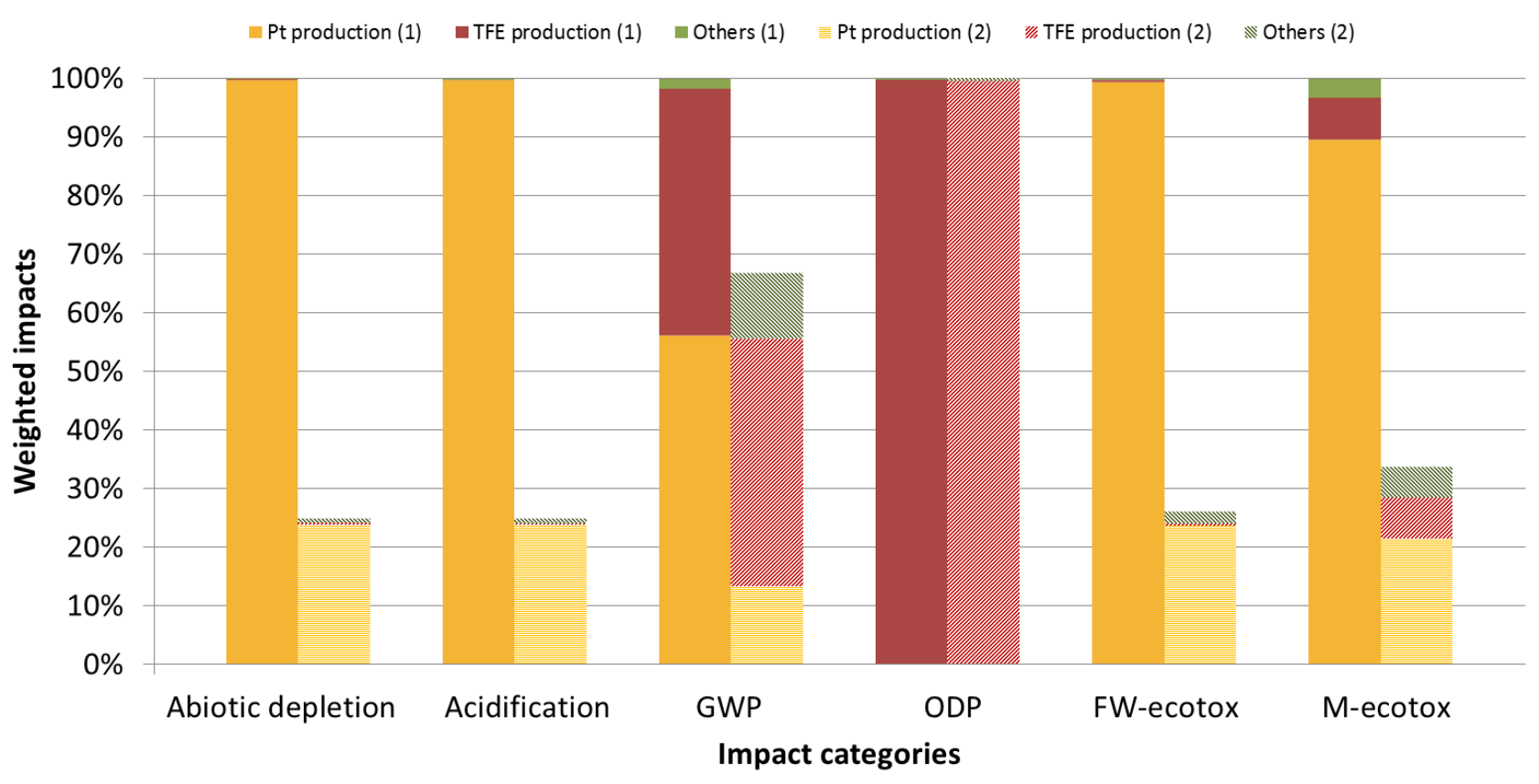

Figure 8: Comparison between the MEA incineration scenario (1) and platinum recycling scenario (2) considering platinum recycling with the $\mathrm{H}_{2} \mathrm{O}_{2}$ /Solvent process.

Despite the fact that the results are in favour of platinum recovery, several aspects need to be considered. Scale-up from the laboratory scale to the industrial scales can radically change these results. Indeed, experiments concerning the current study were performed at the laboratory scale, which implies that energy used for material transport was not evaluated. Moreover, process energy consumption was considered for small sized equipment units, but would differ at the industrial scale. In addition, the MEA disassembly process has not been taken into account in the LCA. Furthermore, tetrafluoroethylene production is the second burden of MEA life-cycle, and its importance in the PEM fuel cell life-cycle is increased, so Nafion ${ }^{\circledR}$ membrane recycling should be investigated.

\section{Conclusions and perspectives}

This study performed the first complete LCA study at the MEA scale. Laboratory data combined with literature data based on valid hypotheses were used to simulate the environmental impacts of the production and end-of-life stages of a $25 \mathrm{~cm}$ active area MEA, whereas four different hydrometallurgical processes for platinum recovery were compared in this study.

LCA simulations performed with SimaPro show that the B process alternative $\left(\mathrm{H}_{2} \mathrm{O}_{2}\right.$ /Solvent recycling process) is the least impacting of the four hydrometallurgical recycling alternatives proposed. Moreover, the assessment reveals that the MEA life-cycle impact can be reduced by $60 \%$ if electrode recycling is carried out at the end-of-life stage of the fuel cell by the $\mathrm{H}_{2} \mathrm{O}_{2}$ /Solvent recycling process. In addition, the main impact category decrease is proportional to the platinum recycling rate. 
The LCA model is based on various simplifying hypotheses and could be improved with a more detailed study. MEA catalyst recycling could be scaled-up at the pilot scale to include a continuous mode (the current study has been performed in batch mode) and the recycling of various solvents (e.g., recirculation of acid, oxidant, etc.). Moreover, a deeper study on the optimisation of the parameters of the recovery process would increase the platinum recovery efficiency and reduce the overall impact.

Concerning the environmental impact assessment, the inventory could eventually be completed by using data on MEA disassembly and membrane and gas diffusion layer recovery. No attempt was made in this direction in this study; however, some ideas to be considered were explored (see details in $\S 3.3$ ). This would represent a step forward in membrane and GDL recycling.

Assuming that the suggested process alternatives for the recycling of MEA would be implemented at the industrial scale, the transport phase to recovery and eventually to the production site should be included in the LCA. On the other hand, the use stage is fully connected to $\mathrm{H}_{2}$ consumption over the use stage of the PEM fuel cell. Finally, a complete assessment at the MEA scale could be integrated in what would be a first complete LCA study on PEM fuel cells, i.e., including the transport and use stages of the fuel cell.

\section{Acknowledgments}

The authors would like to thank the Rhône-Alpes region for financing this project on PEM fuel cell catalyst recycling. Rémi Vincent from the LITEN department of the CEA is highly acknowledged for involvement in this project.

\section{References}

Barakat, M.., Mahmoud, M.H.., 2004. Recovery of platinum from spent catalyst. Hydrometallurgy 72, 179184. doi:10.1016/S0304-386X(03)00141-5

Benson, M., Bennett, C.., Harry, J.., Patel, M.., Cross, M., 2000. The recovery mechanism of platinum group metals from catalytic converters in spent automotive exhaust systems. Resour. Conserv. Recycl. 31, 17. doi:10.1016/S0921-3449(00)00062-8

Bhandari, R., Trudewind, C. a., Zapp, P., 2013. Life cycle assessment of hydrogen production via electrolysis - a review. J. Clean. Prod. doi:10.1016/j.jclepro.2013.07.048

Duclos, L., Svecova, L., Laforest, V., Mandil, G., Thivel, P.-X., 2016. Process development and optimization for platinum recovery from PEM fuel cell catalyst. Hydrometallurgy 160, 79-89. doi:10.1016/j.hydromet.2015.12.013

Fedotov, A.A., Grigoriev, S.A., Millet, P., Fateev, V.N., 2013. Plasma-assisted Pt and Pt-Pd nano-particles deposition on carbon carriers for application in PEM electrochemical cells. Int. J. Hydrogen Energy 38, 8568-8574. doi:10.1016/j.ijhydene.2012.10.042

Garraín, D., 2011. Polymer Electrolyte Membrane Fuel Cells (PEMFC) in Automotive Applications: Environmental Relevance of the Manufacturing Stage. Smart Grid Renew. Energy 02, 68-74. doi:10.4236/sgre.2011.22009 
Hung, C.-J., Liu, C.-H., Wang, C.-H., Chen, W.-H., Shen, C.-W., Liang, H.-C., Ko, T.-H., 2015. Effect of conductive carbon material content and structure in carbon fiber paper made from carbon felt on the performance of a proton exchange membrane fuel cell. Renew. Energy 78, 364-373. doi:10.1016/j.renene.2015.01.021

Hussain, M.M., Dincer, I., Li, X., 2007. A preliminary life cycle assessment of PEM fuel cell powered automobiles. Appl. Therm. Eng. 27, 2294-2299. doi:10.1016/j.applthermaleng.2007.01.015

Iribarren, D., Susmozas, A., Petrakopoulou, F., Dufour, J., 2014. Environmental and exergetic evaluation of hydrogen production via lignocellulosic biomass gasification. J. Clean. Prod. 69, 165-175. doi:10.1016/j.jclepro.2014.01.068

ISO 14040: Environmental management — Life cycle assessment — Principles and framework, 2006.

ISO 14044: Environmental management — Life cycle assessment — Principles and framework, 2006.

James, B., Spisak, A., 2014. Mass Production Cost Estimation of Direct H2 PEM Fuel Cell Systems for Transportation Applications: 2012 Update. Strateg. Anal. Inc. 1-62.

Johnson Matthey, 2013. Platinum 2013, Johnson Matthey technology review. Royston, England.

Jones, D.., 2012. Membrane materials and technology for low temperature fuel cells, in: Hartnig, C., Roth, C. (Eds.), Polymer Electrolyte Membrane and Direct Methanol Fuel Cell Technology. Volume1: Fundamentals and Performance of Low Temperature Fuel Cells. Woodhead Publishing Series in Energy, Cambridge, UK, pp. 27-55.

Jung, C.-Y., Kim, W.-J., Yi, S.-C., 2012. Optimization of catalyst ink composition for the preparation of a membrane electrode assembly in a proton exchange membrane fuel cell using the decal transfer. Int. J. Hydrogen Energy 37, 18446-18454. doi:10.1016/j.ijhydene.2012.09.013

Kadous, A., Meddour-boukhobza, L., Didi, M.A., Villemin, D., 2009. Synthesis and characterization of TOPO and HDADMDPA. Application in uranium (VI) extraction., 213-226.

Labbé, J.-F., Dupuy, J.-J., 2014. 2012 platinum group metals market panorama (in french). Orléans, France.

Liu, C., Xue, X., Lu, T., Xing, W., 2006. The preparation of high activity DMFC Pt/C electrocatalysts using a pre-precipitation method. J. Power Sources 161, 68-73. doi:10.1016/j.jpowsour.2006.03.084

Masoni, P., Zamagni, A., 2011. Guidance Document for performing LCAs on Fuel Cells and Hydrogen Technologies Deliverable D3.3 - Final guidance document, p30.

Oh, H.S., Oh, J.G., Hong, Y.G., Kim, H., 2007. Investigation of carbon-supported Pt nanocatalyst preparation by the polyol process for fuel cell applications. Electrochim. Acta 52, 7278-7285. doi:10.1016/j.electacta.2007.05.080

Oki, T., Katsumata, T., Hashimoto, K., Kobayashi, M., 2009. Recovery of Platinum Catalyst and Polymer Electrolyte from Used Small Fuel Cells by Particle Separation Technology. Mater. Trans. 50, 18641870. doi:10.2320/matertrans.M-M2009812

Park, S., Lee, J.-W., Popov, B.N., 2008. Effect of PTFE content in microporous layer on water management in PEM fuel cells. J. Power Sources 177, 457-463. doi:10.1016/j.jpowsour.2007.11.055

Pehnt, M., 2003. LCA Case Studies Assessing Future Energy and Transport Systems: The Case of Fuel Cells. Int. J. Life Cycle Assess. 8, 365-378.

Pehnt, M., 2001. Life-cycle assessment of fuel cell stacks. Int. J. Hydrogen Energy 26, 91-101. doi:10.1016/S0360-3199(00)00053-7

Pehnt, M., Lamm, A., Gasteiger, H.A., 2003. IS 14040, Life-cycle analysis of fuel cell system components Chapter 94 Life-cycle analysis of fuel cell system components 4, 1293-1317.

Shore, L., 2006. Process for recycling components of a PEM fuel cell membrane electrode assembly. US $8,124,261 \mathrm{~B} 2$.

Simons, A., Bauer, C., 2015. A life-cycle perspective on automotive fuel cells. Appl. Energy. 
doi:10.1016/j.apenergy.2015.02.049

Sørensen, B., Roskilde, D., 2004. Total life-cycle assessment of PEM fuel cell car, in: 15th World Hydrogen Energy Conference. Yokohama, pp. 1-8.

Stephen, G., Walther, G., 2005. Recycling of used perfluorosulfonic acid membranes. US 2005/0211630 A1.

Towne, S., Viswanathan, V., Holbery, J., Rieke, P., 2007. Fabrication of polymer electrolyte membrane fuel cell MEAs utilizing inkjet print technology. J. Power Sources 171, 575-584. doi:10.1016/j.jpowsour.2007.07.017

Veizaga, N., Fernandez, J., Bruno, M., Scelza, O., De Miguel, S., 2012. Deposition of Pt nanoparticles on different carbonaceous materials by using different preparation methods for PEMFC electrocatalysts. Int. J. Hydrogen Energy 37, 17910-17920. doi:10.1016/j.ijhydene.2012.08.144

Velayutham, G., 2011. Effect of micro-layer PTFE on the performance of PEM fuel cell electrodes. Int. J. Hydrogen Energy 36, 14845-14850. doi:10.1016/j.ijhydene.2011.03.037

Verde, Y., Alonso, G., Ramos, V., Zhang, H., Jacobson, A.J., Keer, A., 2004. Pt/C obtained from carbon with different treatments and $\left(\mathrm{NH}_{4}\right)_{2} \mathrm{PtCl}_{6}$ as a Pt precursor. Appl. Catal. A Gen. 277, 201-207. doi:10.1016/j.apcata.2004.09.013

Wang, W., Chen, S., Li, J., Wang, W., 2015. Fabrication of catalyst coated membrane with screen printing method in a proton exchange membrane fuel cell. Int. J. Hydrogen Energy 40, 4649-4658. doi:10.1016/j.ijhydene.2015.02.027

Xu, F., Mu, S., Pan, M., 2010. Recycling of membrane electrode assembly of PEMFC by acid processing. Int. J. Hydrogen Energy 35, 2976-2979. doi:10.1016/j.ijhydene.2009.05.087

Zhao, J., He, X., Tian, J., Wan, C., Jiang, C., 2007. Reclaim/recycle of Pt/C catalysts for PEMFC. Energy Convers. Manag. 48, 450-453. doi:10.1016/j.enconman.2006.06.020

Zucaro, A., Fiorentino, G., Zamagni, A., Bargigli, S., Masoni, P., Moreno, A., Ulgiati, S., 2013. How can life cycle assessment foster environmentally sound fuel cell production and use? Int. J. Hydrogen Energy 38, 453-468. doi:10.1016/j.ijhydene.2012.09.066 
Figure 1: Fuel cell, MEA and electrodes components (adapted from: http://www.theengineer.co.uk).

Figure 2: Flow-sheets of the two studied platinum recovery processes: (left) resin recovery process and (right) liquid/liquid extraction recovery process (Duclos et al., 2016).

Figure 3: Global model diagram of incineration and recycling scenarios, where $R$ is the recovery efficiency of a process alternative.

Figure 4: Mass and energy balance of platinum recovery process from $\mathrm{Pt} / \mathrm{C}$ of the $\mathrm{H}_{2} \mathrm{O}_{2}$ /Solvent process (B).

Figure 5: SimaPro model diagramm of PEMFC MEA production and end-of-life stages (platinum recycling with process $\mathrm{B}$ ).

Figure 6: MEA life cycle hot-spots identification from the scenario (1).

Figure 7: Impact assessment of a $25 \mathrm{~cm}^{2}$ PEM fuel cell MEA considering production and end-of-life stages with the scenario (2).

Figure 8: Comparison between the MEA incineration scenario (1), and the platinum recycling scenario (2) considering platinum recycling with $\mathrm{H}_{2} \mathrm{O}_{2} /$ Solvent process. 


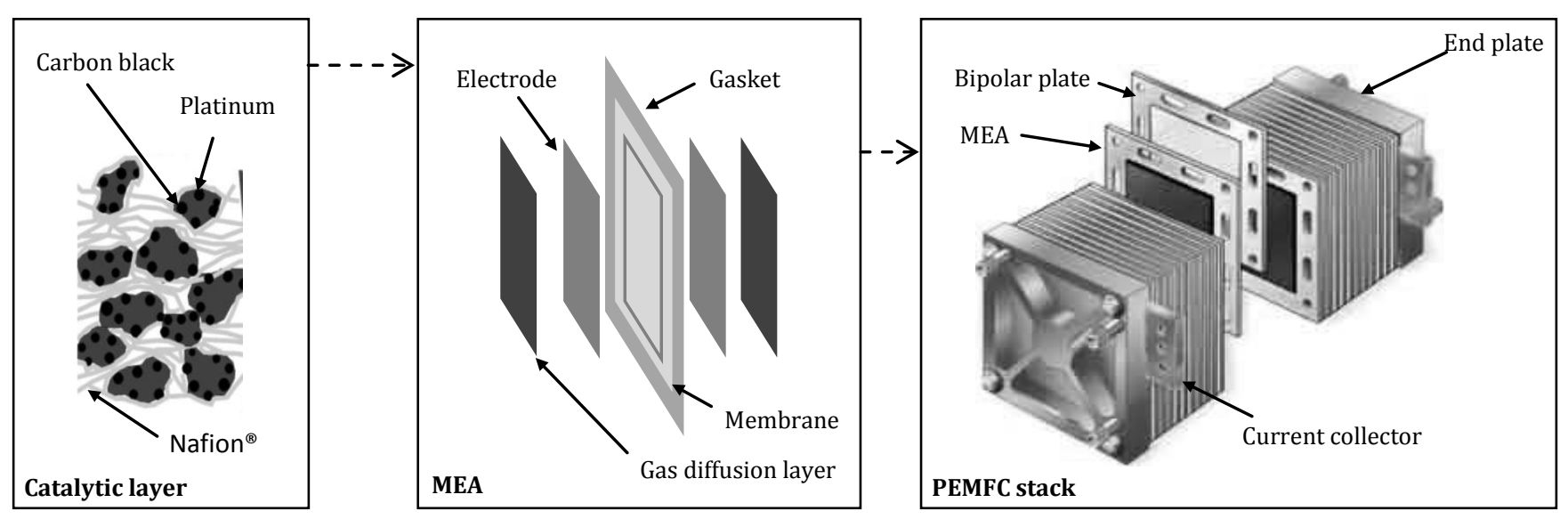

Figure 1: Fuel cell, MEA and electrodes components (adapted from: http://www.theengineer.co.uk). 


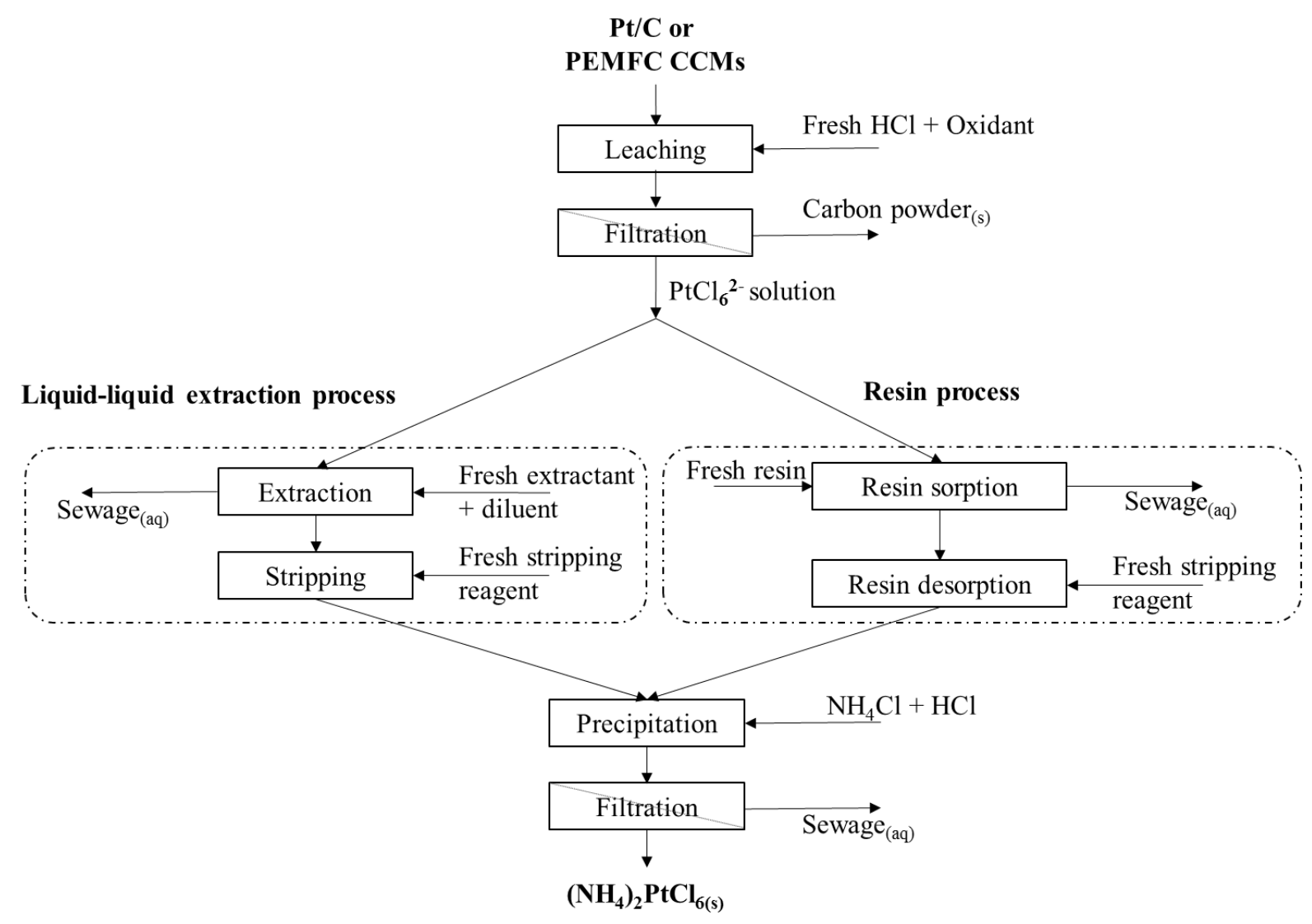

Figure 2: Flow-sheets of the two studied platinum recovery processes: (left) resin recovery process and (right) liquid/liquid extraction recovery process (Duclos et al., 2016). 


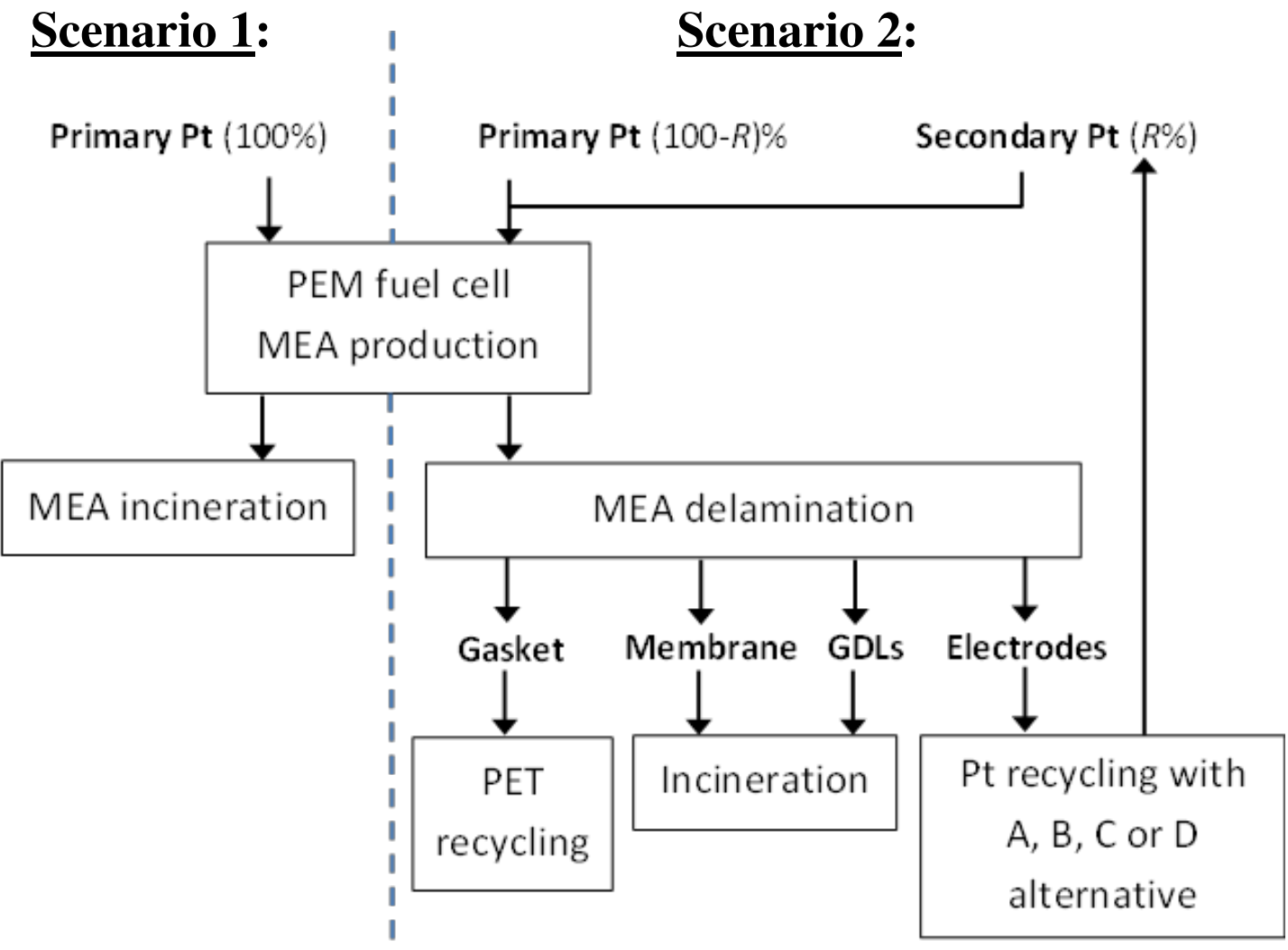

Figure 3: Global model diagram of incineration and recycling scenarios, where $R$ is the recovery efficiency of a process alternative. 


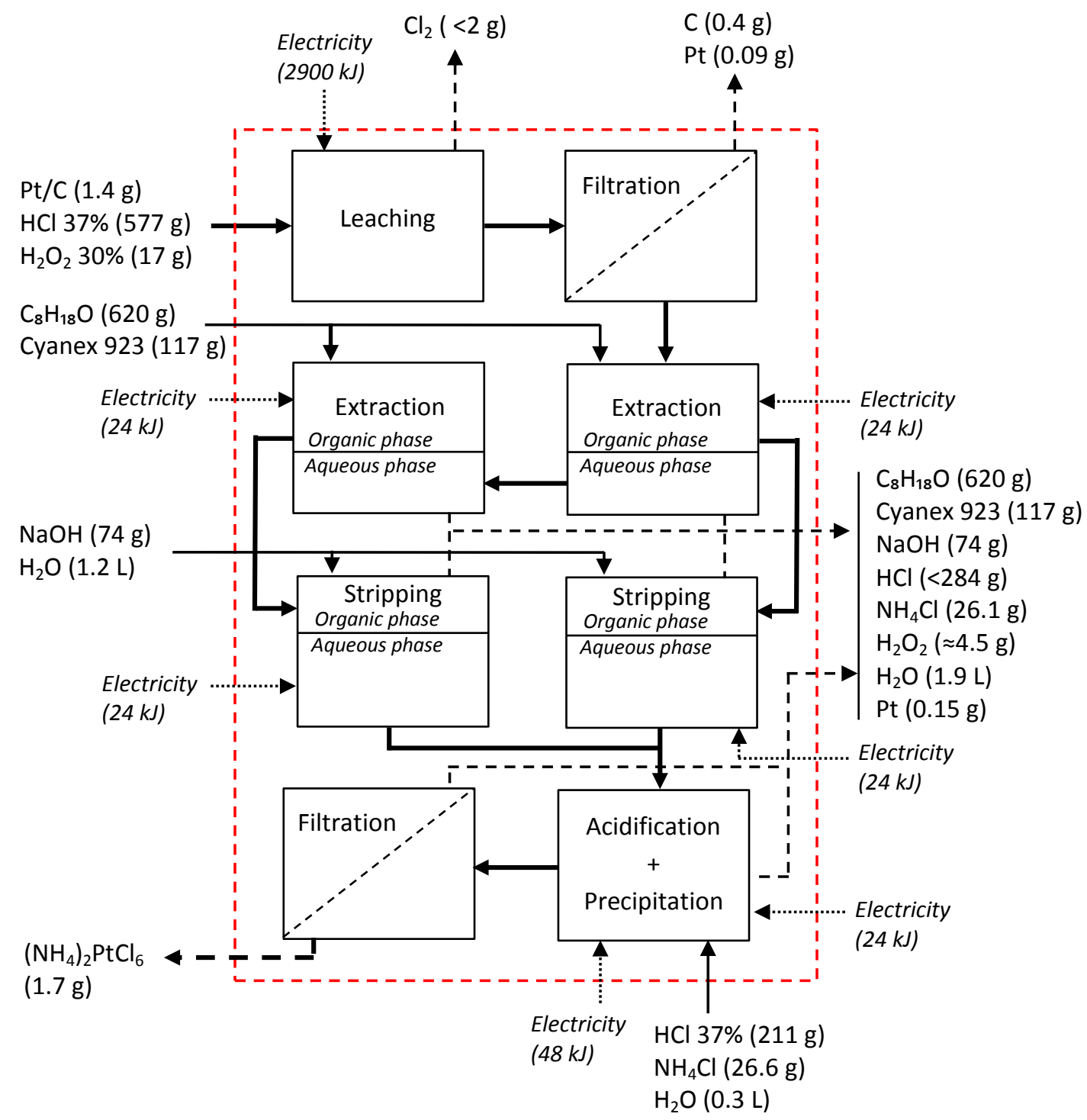

Figure 4: Mass and energy balance of platinum recovery process from $\mathrm{Pt} / \mathrm{C}$ of the $\mathrm{H}_{2} \mathrm{O}_{2} /$ Solvent process (B). 


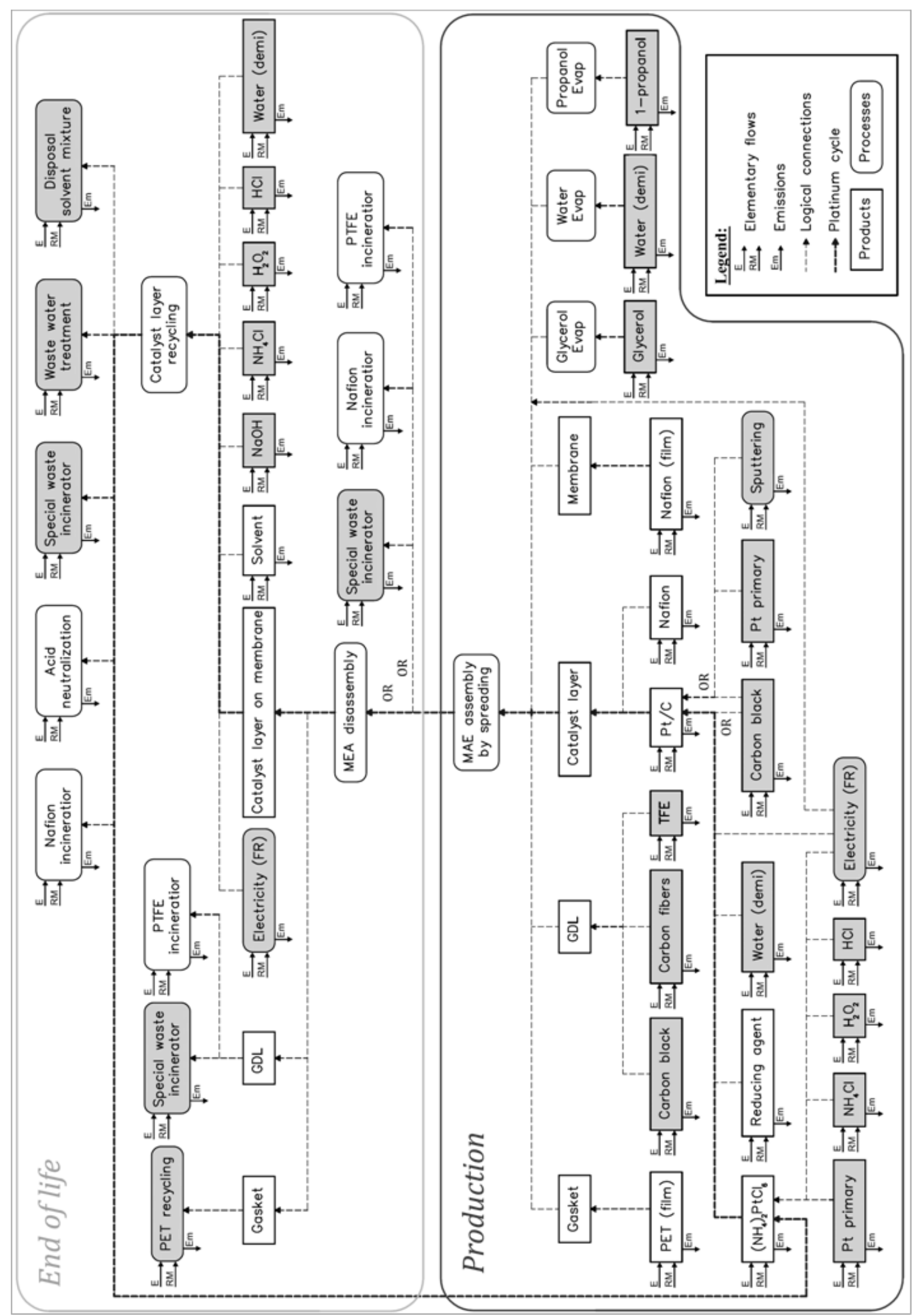

Figure 5: SimaPro model diagramm of PEMFC MEA production and end-of-life stages (platinum recycling with process $\mathrm{B}$ ). 


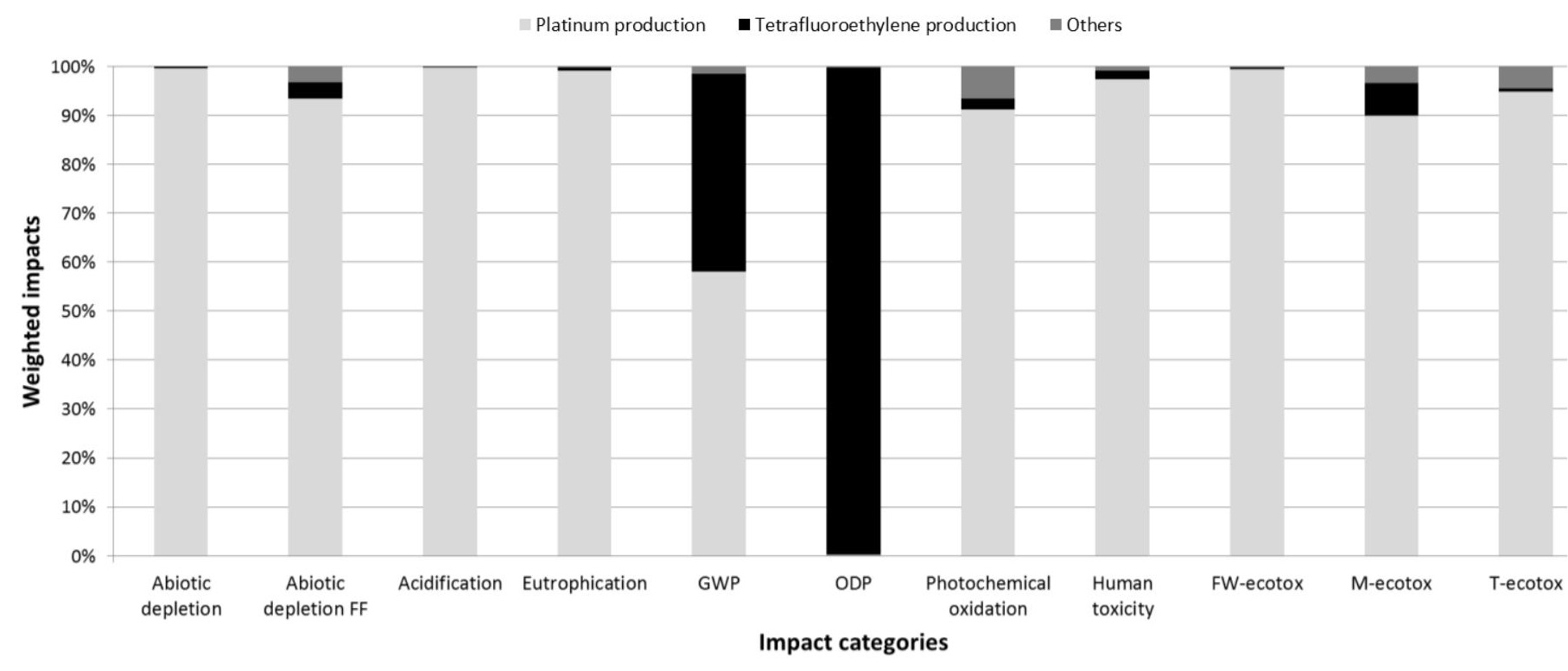

Figure 6: MEA life cycle hot-spots identification from the scenario (1). 


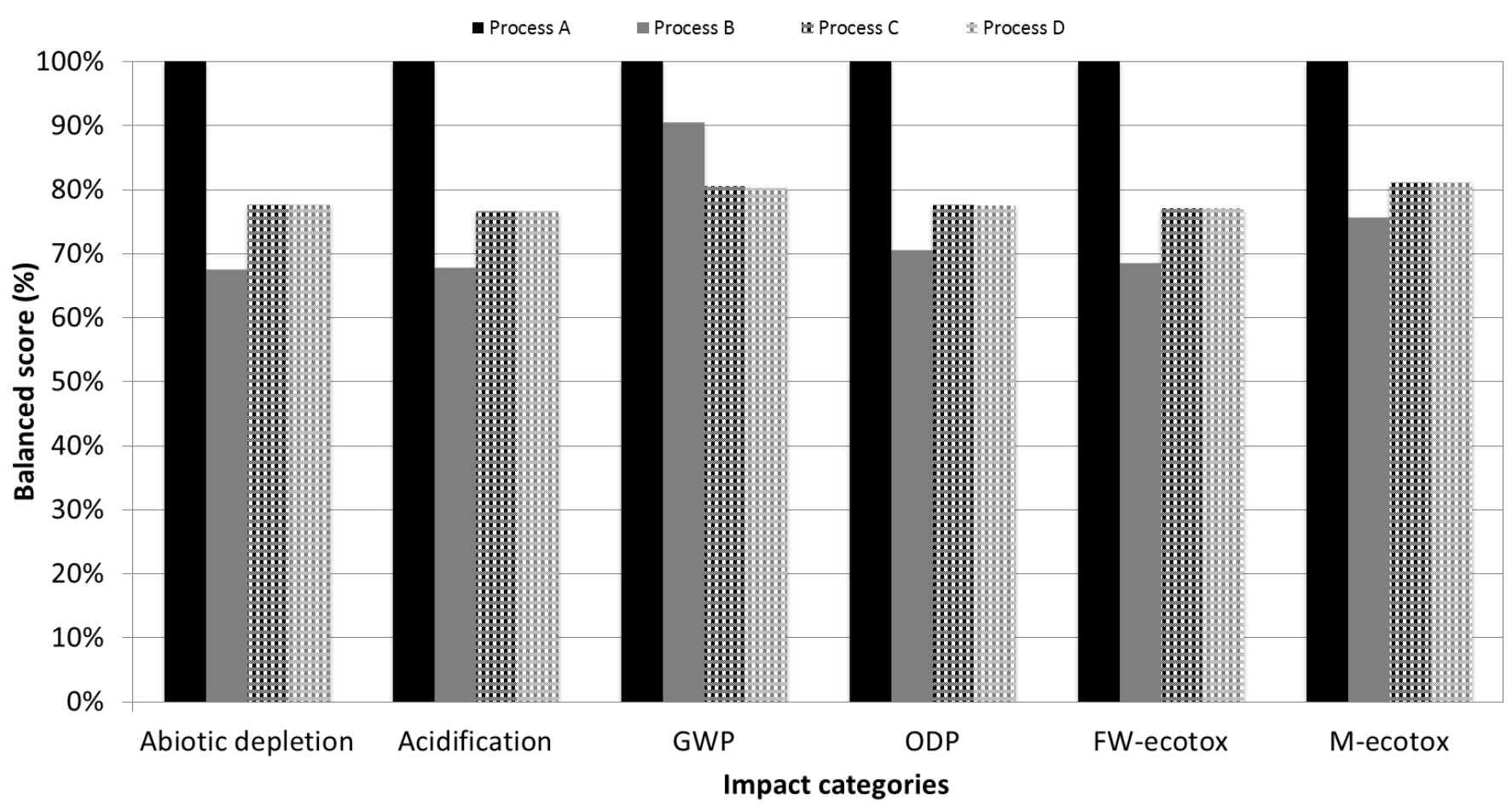

Figure 7: Impact assessment of a $25 \mathrm{~cm}^{2}$ PEM fuel cell MEA considering production and end-of-life stages with the scenario (2). 


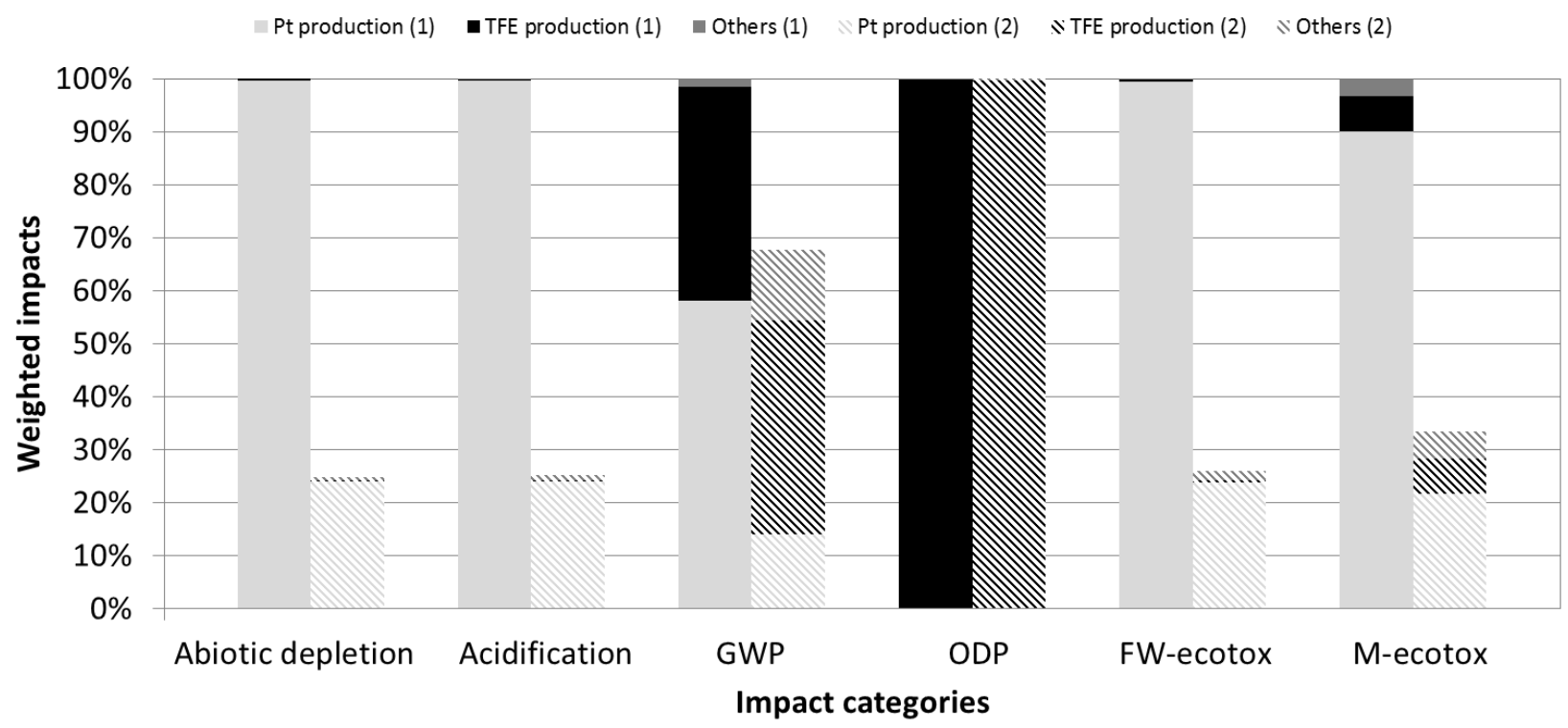

Figure 8: Comparison between the MEA incineration scenario (1), and the platinum recycling scenario (2) considering platinum recycling with $\mathrm{H}_{2} \mathrm{O}_{2}$ /Solvent process. 
Table 1: World platinum market in 2012 (Johnson Matthey, 2013).

\begin{tabular}{lccccc}
\hline & Auto-catalyst & Jewellery & Industrial & Investment & Total \\
\hline Global demand (t) & 91 & 78 & 44 & 13 & $\mathbf{2 2 5}$ \\
Recycling (t) & 32 & 5 & 0 & $/$ & $\mathbf{3 7}$ \\
Recycling rate (\%) & $35 \%$ & $7 \%$ & $1 \%$ & $/$ & $\mathbf{1 7 \%}$ \\
\hline
\end{tabular}


Table 2: MEA manufacturing data.

\begin{tabular}{|c|c|c|c|c|}
\hline MEA components & Materials & $\begin{array}{c}\text { Material/process } \\
\text { available in } \\
\text { EcoInvent }\end{array}$ & $\begin{array}{c}\text { Mass/MEA } \\
\text { surface }\left(\mathrm{kg} \cdot \mathrm{m}^{-2}\right)\end{array}$ & $\begin{array}{c}\text { Reference / } \\
\text { information provider }\end{array}$ \\
\hline \multirow{6}{*}{ Catalyst layer (ink) } & $\begin{array}{c}\text { Platinized carbon } \\
\text { black }\end{array}$ & No & $1.4 \cdot 10^{-2}$ & \multirow{6}{*}{$\begin{array}{c}\text { Paxitech and } \\
\text { (Wang et al., 2015) }\end{array}$} \\
\hline & Water & Yes & $3.0 \cdot 10^{-2}$ & \\
\hline & Propanol & Yes & $1.1 \cdot 10^{-1}$ & \\
\hline & Nafion $^{\circledR}$ & No & $7.4 \cdot 10^{-3}$ & \\
\hline & Cyclohexanol & Yes & $5.5 \cdot 10^{-2}$ & \\
\hline & Ethylene glycol & Yes & $4.8 \cdot 10^{-2}$ & \\
\hline Membrane $^{\mathrm{a}}$ & Nafion $^{\circledR}$ & No & $5.1 \cdot 10^{-1}$ & Chemours website ${ }^{3}$ \\
\hline \multirow{4}{*}{ GDL (carbon paper) ${ }^{\mathrm{a}}$} & Carbon fibre & Yes & $1.8 \cdot 10^{-1}$ & \multirow{4}{*}{$\begin{array}{l}\text { (Park et al., 2008) and } \\
\text { (Hung et al., 2015) }\end{array}$} \\
\hline & Phenolic resin & Yes & $3.2 \cdot 10^{-2}$ & \\
\hline & Carbon black & Yes & $4.0 \cdot 10^{-2}$ & \\
\hline & PTFE & Yes & $3.4 \cdot 10^{-2}$ & \\
\hline Gasket & $\begin{array}{c}\text { Approximated as } \\
\text { PET }\end{array}$ & Yes & $1.7 \cdot 10^{-2}$ & CEA/LITEN \\
\hline Manufacturing step & Energy & & $\begin{array}{c}\text { Energy/MEA } \\
\text { surface }\left(\mathrm{MJ} \cdot \mathrm{m}^{-2}\right)\end{array}$ & Reference \\
\hline Ink production & Electricity & Yes & 5.0 & CEA/LITEN \\
\hline MEA assembly & Electricity & Yes & 8.8 & CEA/LITEN \\
\hline
\end{tabular}

${ }^{\mathrm{a}}$ Membrane and GDL data without to pre-treatment material losses consideration. 
Table 3: Additional products in SimaPro.

\begin{tabular}{|c|c|c|c|}
\hline Material & $\begin{array}{c}\text { SimaPro associated } \\
\text { product }\end{array}$ & $\begin{array}{c}\text { Composition product/material } \\
\text { mass ratios }\left(\mathrm{kg} \cdot \mathrm{kg}^{-1}\right)\end{array}$ & Process \\
\hline Nafion $^{(\circledR)}$ & $\mathrm{PTFE}+\mathrm{H}_{2} \mathrm{SO}_{4}$ & $0.85+0.18$ & / \\
\hline $\mathrm{Pt} / \mathrm{C}(70 \% \mathrm{Pt})$ & $\mathrm{Pt}+$ Carbon black & $0.7+0.3$ & Metal sputtering \\
\hline Cyanex ${ }^{\circledR} 923$ & $\mathrm{POCl}_{3}+\mathrm{C}_{8} \mathrm{H}_{18}$ & $0.4+0.88$ & / \\
\hline
\end{tabular}


Table 4: Additional waste treatment processes in SimaPro.

Nafion ${ }^{\circledR}$ incineration

PTFE incineration

Fluorine content $59 \%$ $76 \%$

PVF incineration $\left(\mathrm{kg}^{\mathrm{kg}}{ }^{-1}\right)$

1.1

1.4 
Table 5: Efficiency of $\mathrm{Pt}$ recovery processes (Duclos et al., 2016).

\begin{tabular}{lcccc}
\hline Recovery process denomination & $\mathbf{A}$ & B & C & D \\
\hline Extraction process & \multicolumn{2}{c}{ Solvent } & \multicolumn{2}{c}{ Resin } \\
\hline Leachate & $\mathrm{HNO}_{3}$ & $\mathrm{H}_{2} \mathrm{O}_{2}$ & $\mathrm{HNO}_{3}$ & $\mathrm{H}_{2} \mathrm{O}_{2}$ \\
\hline Leaching & $93 \%$ & $91 \%$ & $93 \%$ & $91 \%$ \\
Separation & $81 \%$ & $86 \%$ & $86 \%$ & $89 \%$ \\
Precipitation & $85 \%$ & $97 \%$ & $90 \%$ & $89 \%$ \\
\hline Efficiency (\% of Pt recovered) & $\mathbf{6 4 \%}$ & $\mathbf{7 6 \%}$ & $\mathbf{7 2 \%}$ & $\mathbf{7 2 \%}$ \\
\hline
\end{tabular}


Table 6: Recycling processes energy and mass balance including wastes treatment (amounts per kg of Pt at process inlet).

\section{Process inlets}

\begin{tabular}{lccccc}
\hline \multirow{2}{*}{\multicolumn{1}{c}{ Products/ }} & energy & \multicolumn{4}{c}{ Process } \\
\cline { 2 - 6 } & Recycling process & & B & C & D \\
\hline Nafion ${ }^{\circledR}(\mathrm{kg})$ & & 0.7 & 0.7 & 0.7 & 0.7 \\
$\mathrm{Pt} / \mathrm{C}(\mathrm{kg})$ & 1.4 & 1.4 & 1.4 & 1.4 \\
$\mathrm{HCl}$ without water $(\mathrm{kg})$ & 279 & 284 & 265 & 269 \\
$\mathrm{HNO}_{3}$ without water $(\mathrm{kg})$ & 25 & $/$ & 25 & $/$ \\
$\mathrm{H}_{2} \mathrm{O}_{2}$ without water $(\mathrm{kg})$ & $/$ & 5 & $/$ & 5 \\
Deionised water $(\mathrm{kg})$ & 1900 & 1900 & 1700 & 1700 \\
Cyanex ${ }^{\circledR} 923(\mathrm{~kg})$ & 117 & 117 & $/$ & $/$ \\
Pentanol $(\mathrm{kg})$ & 620 & 620 & $/$ & $/$ \\
Anionic resin $(\mathrm{kg})$ & & $/$ & $/$ & 40 & 40 \\
$\mathrm{NaOH}$ without water $(\mathrm{kg})$ & & 74 & 74 & 40 & 40 \\
$\mathrm{NH}$ & & 26.6 & 26.6 & 21.4 & 21.4 \\
\hline Electricity $(\mathrm{kg})$ & & 3000 & 3000 & 4000 & 4000 \\
\hline
\end{tabular}

\section{Wastes or products/}

Process

treatment process

\begin{tabular}{|c|c|c|c|c|c|}
\hline \multirow{7}{*}{ Solid wastes } & $\mathrm{Pt}(\mathrm{kg})$ & 0.36 & 0.24 & 0.28 & 0.28 \\
\hline & $\mathrm{C}(\mathrm{kg})$ & 0.4 & 0.4 & 0.4 & 0.4 \\
\hline & Hazardous waste, for incineration $\{G L O\}(\mathrm{kg})$ & 0.8 & 0.7 & 0.7 & 0.7 \\
\hline & Nafion ${ }^{\circledR}(\mathrm{kg})$ & 0.7 & 0.7 & 0.7 & 0.7 \\
\hline & Nafion incinerator $(\mathrm{kg})$ & 0.7 & 0.7 & 0.7 & 0.7 \\
\hline & Anionic resin $(\mathrm{kg})$ & l & / & 40 & 40 \\
\hline & $\begin{array}{l}\text { Spent anion exchange resin from potable water production }\{G L O\} \\
(\mathrm{kg})\end{array}$ & / & / & 80 & 80 \\
\hline \multirow{9}{*}{ Aqueous wastes } & $\mathrm{HCl}(\mathrm{kg})$ & 279 & 283 & 264 & 268 \\
\hline & $\mathrm{HNO}_{3}(\mathrm{~kg})$ & 24 & 1 & 24 & 1 \\
\hline & Hydrochloric acid neutralization $(\mathrm{kg})$ & 279 & 284 & 265 & 269 \\
\hline & Nitric acid neutralization $(\mathrm{kg})$ & 25 & 1 & 25 & 1 \\
\hline & Deionised water $(\mathrm{kg})$ & 1900 & 1900 & 1700 & 1700 \\
\hline & $\mathrm{H}_{2} \mathrm{O}_{2}(\mathrm{~kg})$ & l & 4 & l & 4 \\
\hline & $\mathrm{NaOH}(\mathrm{kg})$ & 74 & 74 & 40 & 40 \\
\hline & $\mathrm{NH}_{4} \mathrm{Cl}(\mathrm{kg})$ & 26.2 & 26.1 & 21.0 & 21.0 \\
\hline & $\begin{array}{l}\text { Wastewater, average }\{\mathrm{CH}\} \text { treatment of capacity } 4.7 \text { E10l/year } \\
\left(\mathrm{m}^{3}\right)\end{array}$ & 1.9 & 1.9 & 1.7 & 1.7 \\
\hline \multirow{3}{*}{ Organic wastes } & Cyanex ${ }^{\circledR} 923(\mathrm{~kg})$ & 117 & 117 & l & / \\
\hline & Pentanol $(\mathrm{kg})$ & 620 & 620 & 1 & 1 \\
\hline & Spent solvent mixture $\{G L O](\mathrm{kg})$ & 737 & 737 & 1 & l \\
\hline Products & $\left(\mathrm{NH}_{4}\right)_{2} \mathrm{PtCl}_{6}(\mathrm{~kg})$ & 1.47 & 1.73 & 1.64 & 1.64 \\
\hline
\end{tabular}


Table 7: CML-IA baseline V3.02 method impact categories.

\begin{tabular}{lc}
\hline \multicolumn{1}{c}{ Impact category } & Unit \\
\hline Abiotic depletion & $(\mathrm{kg} \mathrm{Sb} \mathrm{eq})$ \\
Abiotic depletion fossil fuels & $(\mathrm{MJ})$ \\
Acidification & $\left(\mathrm{kg} \mathrm{SO}_{2} \mathrm{eq}\right)$ \\
Eutrophication & $\left(\mathrm{kg} \mathrm{PO}_{4}{ }^{3-} \mathrm{eq}\right)$ \\
Global warming potential & $\left(\mathrm{kg} \mathrm{CO}_{2} \mathrm{eq}\right)$ \\
Ozone layer depletion & $\left(\mathrm{kg} \mathrm{CFC}^{-11} \mathrm{eq}\right)$ \\
Photochemical oxidation & $\left(\mathrm{kg} \mathrm{C}_{2} \mathrm{H}_{4}\right)$ \\
Human toxicity & $(\mathrm{kg} \mathrm{1.4-DB} \mathrm{eq)})$ \\
Fresh water aquatic ecotoxicity & $(\mathrm{kg} \mathrm{1,4-DB} \mathrm{eq)}$ \\
Marine aquatic ecotoxicity & $(\mathrm{kg} \mathrm{1.4-DB} \mathrm{eq)}$ \\
Terrestrial ecotoxicity & $(\mathrm{kg} \mathrm{1.4-DB} \mathrm{eq)}$ \\
\hline
\end{tabular}


Table 8: Impact categories burdens in the life cycle normalised impact score for scenario (2)-B process.

\begin{tabular}{|c|c|}
\hline Impact category & $\begin{array}{c}\text { Category score } \\
\text { weighting }\end{array}$ \\
\hline Abiotic depletion & $0.9 \%$ \\
\hline Abiotic depletion (fossil fuels) & $0.5 \%$ \\
\hline Acidification & $4 \%$ \\
\hline Eutrophication & $0.7 \%$ \\
\hline GWP & $0.8 \%$ \\
\hline ODP & $0.8 \%$ \\
\hline Photochemical oxidation & $0.6 \%$ \\
\hline Human toxicity & $0.4 \%$ \\
\hline FW-ecotox & $6 \%$ \\
\hline M-ecotox & $86 \%$ \\
\hline T-ecotox & $<0.1 \%$ \\
\hline
\end{tabular}

